\title{
Preliminary Evaluation of the Section 1603 Treasury Grant Program for Renewable Power Projects in the United States
}

\author{
Submitted to: Energy Policy \\ Mark Bolinger ${ }^{*}$, Ryan Wiser, Naïm Darghouth \\ Lawrence Berkeley National Laboratory, MS 90-4000, One Cyclotron Road, Berkeley, \\ California 94720
}

\begin{abstract}
This article evaluates the first year of the Section 1603 Treasury cash grant program, which enables renewable power projects in the U.S. to elect cash grants in lieu of the federal tax credits that are otherwise available. To date, the program has been heavily subscribed, particularly by wind power projects, which had received $86 \%$ of the nearly $\$ 2.6$ billion in grants that had been disbursed as of March 1, 2010. As of that date, $6.2 \mathrm{GW}$ of the $10 \mathrm{GW}$ of new wind capacity installed in the U.S. in 2009 had applied for grants in lieu of production tax credits. Roughly 2.4 GW of this wind capacity may not have otherwise been built in 2009 absent the grant program; this 2.4 GW may have supported approximately 51,600 short-term full-time-equivalent (FTE) gross job-years in the U.S. during the construction phase of these wind projects, and 3,860 longterm FTE gross jobs during the operational phase. The program's popularity stems from the significant economic value that it provides to renewable power projects, relative to the otherwise available tax credits. Although grants reward investment rather than efficient performance, this evaluation finds no evidence at this time of either widespread "gold-plating" or performance problems.
\end{abstract}

Keywords: wind power, cash versus tax incentives, financing

\footnotetext{
* Corresponding author. Tel.: 0016037954937.

E-mail addresses: MABolinger@lbl.gov (M. Bolinger), RHWiser@lbl.gov (R. Wiser), NDarghouth@lbl.gov (N. Darghouth).
} 


\section{Introduction}

Federal support for renewable energy deployment in the United States has traditionally been delivered primarily through tax benefits, including the production tax credit ("PTC"), the investment tax credit (“ITC”), and accelerated tax depreciation. ${ }^{1}$ Many renewable power project developers are unable to use the majority of these tax benefits directly or immediately, however, and have therefore often turned to third-party "tax equity" investors that can monetize the available tax benefits while also providing investment capital. As has been well-publicized, most of these tax equity investors - which have consisted primarily of large banks and insurance companies - were hit hard by the global financial crisis that unfolded in the last months of 2008 and, as a result, most either withdrew from the renewable power market at that time or reduced their available investment capital. This left a significant financing gap beginning in late 2008, and placed at some risk the continued near-term growth of renewable energy supply in the U.S.

In recognition of these developments, as well as the ongoing deterioration of the broader economy, the U.S. Congress passed The American Recovery and Reinvestment Act ("the Recovery Act”) in February 2009. Parts of the Recovery Act were intended to address the growing shortage of finance for renewable power projects. Most notably, Section 1603 of the Recovery Act enables qualifying commercial renewable energy projects to elect a $30 \%$ cash grant in lieu of the pre-existing PTC or ITC. By giving developers the option to receive a 30\% cash grant (administered by the U.S. Department of the Treasury) instead of either the ITC or the PTC, Congress hoped to "...temporarily fill the gap created by the diminished investor demand for tax credits,” and thereby achieve “...the near term goal of creating and retaining jobs...as well as the long-term benefit of expanding the use of clean and renewable energy and decreasing our dependency on non-renewable energy sources” (U.S. Department of the Treasury 2009).

This article, which is based on a longer LBNL report (Bolinger et al. 2010), represents an initial attempt at evaluating the Section 1603 Treasury grant program in light of these goals. The evaluation focuses primarily on the commercial wind power sector, for two reasons: (1) commercial wind power projects had received nearly $86 \%$ of all grant money awarded as of March 1, 2010; and (2) there is substantially more market-related information available for the commercial wind power sector than there is for other renewable power sectors, thereby facilitating analysis. Despite the focus on wind power, this analysis does endeavor to provide relevant information on other technologies, and in particular geothermal (the second-largest recipient of grant money), where possible.

The article proceeds as follows:

- Section 2 demonstrates heavy use of the program by summarizing the Section 1603 grants awarded to all technologies as of March 1, 2010, and by providing more detail on those grants awarded to both large wind and geothermal power projects.

- Section 3 focuses specifically on the large wind power sector, with the goal of assessing the grant program's impact on wind power deployment in calendar year 2009. Two

\footnotetext{
${ }^{1}$ The PTC resides within Section 45 of Title 26 of the U.S. Code; Title 26 is also known as the Internal Revenue Code or simply "the tax code." Sections 25D and 48 of the tax code provide ITCs for residential and commercial taxpayers, respectively, who invest in qualified technologies, while Section 168 of the tax code allows 5-year accelerated tax depreciation for qualified investments in certain types of renewable energy projects.
} 
complementary methods are used for this purpose: first, the actual amount of large wind power capacity installed in the U.S. in 2009 is compared to earlier expectations of 2009 capacity additions; second, a qualitative review of each individual 2009 wind power project that selected the grant is conducted to determine whether or not that project likely needed the grant, or instead likely would have been built under the PTC if the grant option did not exist.

- Section 4 continues the focus on wind power, and uses an economic input-output model to roughly estimate the potential gross employment impacts of the program within the wind power sector.

- Section 5 discusses the economic value that Section 1603 grants provide to renewable energy projects. This value is broken down into three non-overlapping components: the financing advantage that the grant provides in the absence of tax equity (on in the presence of expensive tax equity); the grant's "direct" or "face" value relative to the PTC; and the "indirect” or "ancillary” benefits of the grant relative to the PTC or ITC.

- Section 6 addresses potential concerns surrounding the design and implementation of the Section 1603 program. These concerns include free-ridership (and its cost), the fact that the grant rewards investment rather than performance (which could potentially lead to "goldplating” and/or poor performance), and the location of job support (i.e., foreign versus domestic).

- $\quad$ Section 7 concludes with a summary of key findings. 


\section{Summary of Section 1603 Grants Awarded as of March 1, 2010}

Though created as part of the Recovery Act that became law on February 17, 2009, the Section 1603 cash grant program was not fully implemented until July 2009, when the Treasury posted guidance documents (on July 9) and began to accept applications (on July 31). ${ }^{2}$ The first $\$ 500$ million in grant awards were announced on September 1, 2009, and since that time, the Treasury has awarded (as of March 1, 2010) nearly \$2.6 billion in Section 1603 grants to 392 projects.

Table 1. Summary of Grants Awarded as of March 1, 2010

\begin{tabular}{|l|r|r|r|r|r|r|}
\hline & $\begin{array}{c}\text { Number } \\
\text { of } \\
\text { Projects }\end{array}$ & $\begin{array}{c}\text { Total } \\
\text { Capacity } \\
(\mathrm{MW})\end{array}$ & $\begin{array}{c}\text { Grants } \\
\text { Awarded } \\
(\$)\end{array}$ & $\begin{array}{c}\text { \% of } \\
\text { Grants } \\
\text { Awarded }\end{array}$ & $\begin{array}{c}\text { Average } \\
\text { Basis } \\
(\$ / \mathrm{kW})\end{array}$ & $\begin{array}{c}\text { Average } \\
\text { Estimated } \\
\text { Capacity } \\
\text { Factor }\end{array}$ \\
\hline Biomass & 8 & 129.9 & $\$ 72,509,899$ & $2.8 \%$ & $\$ 1,860$ & $63.1 \%$ \\
\hline Combined Heat \& Power & 2 & 0.9 & $\$ 436,473$ & $0.0 \%$ & $\$ 4,988$ & $46.6 \%$ \\
\hline Fuel Cell & 4 & 1.2 & $\$ 2,770,235$ & $0.1 \%$ & -- & $78.8 \%$ \\
\hline Geothermal Electric (new equipment) & 2 & 11.6 & $\$ 2,224,148$ & $0.1 \%$ & $\$ 639$ & $91.3 \%$ \\
\hline Geothermal Electric (new plant) & 4 & 125.4 & $\$ 152,383,474$ & $5.9 \%$ & $\$ 4,051$ & $74.2 \%$ \\
\hline Geothermal Heat Pump & 4 & -- & $\$ 54,853$ & $0.0 \%$ & -- & -- \\
\hline Hydropower (incremental) & 2 & 8.5 & $\$ 4,078,644$ & $0.2 \%$ & $\$ 1,609$ & $49.8 \%$ \\
\hline Landfill Gas & 4 & 20.5 & $\$ 12,864,644$ & $0.5 \%$ & $\$ 2,090$ & $88.6 \%$ \\
\hline Solar Heat \& Hot Water & 20 & -- & $\$ 839,906$ & $0.0 \%$ & -- & -- \\
\hline Solar Photovoltaic & 280 & 50.0 & $\$ 94,940,363$ & $3.7 \%$ & $\$ 6,332$ & $17.5 \%$ \\
\hline Solar Thermal Electric (new equipment) & 1 & 5.8 & $\$ 2,913,273$ & $0.1 \%$ & $\$ 1,674$ & $11.5 \%$ \\
\hline Solar Thermal Electric (new plant) & 1 & 5.0 & $\$ 19,543,649$ & $0.8 \%$ & $\$ 13,029$ & $9.7 \%$ \\
\hline Wind (Small) & 20 & 0.7 & $\$ 883,009$ & $0.0 \%$ & $\$ 4,359$ & $20.4 \%$ \\
\hline Wind (Large) & 40 & $3,891.8$ & $\$ 2,225,671,487$ & $85.9 \%$ & $\$ 1,906$ & $34.4 \%$ \\
\hline \multicolumn{1}{|c|}{ Total: } & $\mathbf{3 9 2}$ & $\mathbf{4 , 2 5 1 . 2}$ & $\mathbf{\$ 2 , 5 9 2 , 1 1 4 , 0 5 7}$ & $\mathbf{1 0 0 . 0 \%}$ & & \\
\hline
\end{tabular}

Table 1 summarizes, by technology, the grants awarded through March 1, 2010. ${ }^{3}$ As shown, large wind power projects had received nearly $86 \%$ of grant awards at that time, followed by geothermal electric with nearly $6.0 \%$, solar photovoltaic at $3.7 \%$, and biomass at $2.8 \%{ }^{4}$ In total, 4.25 GW of renewable power projects have come online and been supported by these grants through March 1; additionally, some grant dollars have gone to non-electrical projects, such as geothermal heat pumps and solar hot water systems. With the possible exception of the single new solar thermal electric plant, ${ }^{5}$ none of the average $\$ / \mathrm{kW}$ basis or capacity factor estimates within a technology category seem out of line with common understanding of the typical cost and performance of renewable power projects (this point is discussed further in Section 6.2 of this article). ${ }^{6}$

\footnotetext{
${ }^{2}$ Grant applications can be submitted at any time and are evaluated (for completeness, eligibility, etc.) and awarded on a "first-come, first-served" basis - i.e., this is not a competitive solicitation process.

${ }^{3}$ Data on project capacity and estimated annual electricity generation (used to calculate estimated capacity factor) were provided by the Treasury. All other data are from http://www.treasury.gov/recovery/docs/Web\%20Posting.xls (and are updated on a weekly basis).

${ }^{4}$ Wind and geothermal also account for $86 \%$ and 6\%, respectively, of estimated electricity generation.

${ }^{5}$ eSolar's 5 MW Sierra SunTower plant in California is currently the only commercially operating solar thermal power tower plant in the United States, which - along with its relatively small size and the fact that it is eSolar's first commercial demonstration facility - may explain its seemingly higher-than-expected costs (i.e., $>\$ 13 / \mathrm{W}$ ) and lowerthan-expected capacity factor (i.e., <10\%).

${ }^{6}$ The "basis" is simply the dollar amount to which the Section 1603 grant is applied. The $\$ / \mathrm{kW}$ basis is derived for each technology by dividing the total grant amount by either $10 \%$ (for combined heat \& power projects) or $30 \%$ (for all other technologies), and then dividing by the total capacity (in $\mathrm{kW}$ ) supported by the grant. It was not possible to
} 
Table 2. Details of Large Wind Power Projects Awarded Grants as of March 1, 2010

\begin{tabular}{|c|c|c|c|c|c|c|c|}
\hline State & $\begin{array}{l}\text { Project } \\
\text { Name }\end{array}$ & $\begin{array}{c}\text { Sponsor } \\
\text { Name }\end{array}$ & $\begin{array}{c}\text { Capacity } \\
\text { Supported by } \\
\text { Grant (MW) }\end{array}$ & $\begin{array}{l}\text { Grant } \\
\text { Size } \\
(\$)\end{array}$ & $\begin{array}{l}\text { Grant } \\
\text { Basis } \\
(\$ / k W)\end{array}$ & $\begin{array}{l}\text { Turbine } \\
\text { Make }\end{array}$ & $\begin{array}{l}\text { Estimated } \\
\text { Capacity } \\
\text { Factor }\end{array}$ \\
\hline$A Z$ & Dry Lake & Iberdrola & 63.00 & $\$ 31,345,799$ & $\$ 1,659$ & Suzlon & $24.0 \%$ \\
\hline CA & Garnet & Garnet Energy Corp. & 5.50 & $\$ 2,711,969$ & $\$ 1,644$ & NedWind & $34.2 \%$ \\
\hline $\mathrm{CO}$ & Northern Colorado & NextEra & 174.30 & $\$ 99,900,326$ & $\$ 1,911$ & Siemens/GE & $41.1 \%$ \\
\hline IA & Barton & Iberdrola & 160.00 & $\$ 93,419,883$ & $\$ 1,946$ & Gamesa & $36.9 \%$ \\
\hline ID & Cassia & John Deere & 10.50 & $\$ 5,123,426$ & $\$ 1,626$ & Suzlon & $25.7 \%$ \\
\hline ID & Cassia Gulch & John Deere & 18.90 & $\$ 9,212,592$ & $\$ 1,625$ & Suzlon & $25.7 \%$ \\
\hline IL & Blackstone & Horizon & 102.00 & $\$ 55,202,420$ & $\$ 1,804$ & GE & $31.9 \%$ \\
\hline IL & EcoGrove & Acciona & 100.50 & $\$ 67,868,807$ & $\$ 2,251$ & Acciona & $31.6 \%$ \\
\hline IL & Grand Ridge II & Invenergy & 51.00 & $\$ 32,300,165$ & $\$ 2,111$ & GE & $31.5 \%$ \\
\hline IL & Grand Ridge III & Invenergy & 49.50 & $\$ 32,094,053$ & $\$ 2,161$ & GE & $31.5 \%$ \\
\hline IL & Rail Splitter & Horizon & 100.50 & $\$ 61,447,344$ & $\$ 2,038$ & GE & $33.4 \%$ \\
\hline IN & Hoosier & enXco & 106.00 & $\$ 69,555,205$ & $\$ 2,187$ & REpower & $39.1 \%$ \\
\hline IN & Meadow Lake & Horizon & 199.65 & $\$ 113,181,518$ & $\$ 1,890$ & Vestas & $32.0 \%$ \\
\hline MA & Forbes Park & Forbes Park & 0.60 & $\$ 620,685$ & $\$ 3,448$ & Elecon & $18.7 \%$ \\
\hline MA & \multicolumn{2}{|c|}{ Mark Richey Woodworking } & 0.60 & $\$ 569,734$ & $\$ 3,165$ & Elecon & $23.5 \%$ \\
\hline $\mathrm{ME}$ & Stetson & First Wind & 57.00 & $\$ 40,441,471$ & $\$ 2,365$ & GE & $30.8 \%$ \\
\hline $\mathrm{Ml}$ & Stoney Corners & Heritage Sust. Energ. & 14.00 & $\$ 9,016,266$ & $\$ 2,147$ & REpower & $28.0 \%$ \\
\hline $\mathrm{MN}$ & Moraine II & Iberdrola & 49.50 & $\$ 28,019,520$ & $\$ 1,887$ & $\mathrm{GE}$ & $39.0 \%$ \\
\hline $\mathrm{MO}$ & Farmers City & Iberdrola & 146.00 & $\$ 84,959,857$ & $\$ 1,940$ & Gamesa & $36.7 \%$ \\
\hline MT & Glacier II & Naturener & 103.50 & $\$ 62,249,825$ & $\$ 2,005$ & Acciona & $33.6 \%$ \\
\hline ND & Luverne & Otter Tail Power & 49.50 & $\$ 30,182,104$ & $\$ 2,032$ & GE & $42.9 \%$ \\
\hline NY & Cohocton & First Wind & 87.50 & $\$ 52,352,334$ & $\$ 1,994$ & Clipper & $23.5 \%$ \\
\hline NY & Dutch Hill & First Wind & 37.50 & $\$ 22,296,494$ & $\$ 1,982$ & Clipper & $23.6 \%$ \\
\hline OR & Hay Canyon & Iberdrola & 100.80 & $\$ 47,092,555$ & $\$ 1,557$ & Suzlon & $29.9 \%$ \\
\hline OR & Pebble Springs & Iberdrola & 98.70 & $\$ 46,543,219$ & $\$ 1,572$ & Suzlon & $32.0 \%$ \\
\hline OR & Vansycle II & NextEra & 98.90 & $\$ 55,386,898$ & $\$ 1,867$ & Siemens & $36.2 \%$ \\
\hline OR & Wheat Field & Horizon & 96.60 & $\$ 47,717,155$ & $\$ 1,647$ & Suzlon & $28.0 \%$ \\
\hline PA & Armenia Mountain & AES & 100.50 & $\$ 69,460,892$ & $\$ 2,304$ & GE & $32.6 \%$ \\
\hline PA & Highland & Everpower & 62.50 & $\$ 42,204,562$ & $\$ 2,251$ & Nordex & $28.5 \%$ \\
\hline PA & Locust Ridge II & Iberdrola & 102.00 & $\$ 59,162,064$ & $\$ 1,933$ & Gamesa & $26.9 \%$ \\
\hline TX & Barton Chapel & Iberdrola & 120.00 & $\$ 72,573,627$ & $\$ 2,016$ & Gamesa & $32.1 \%$ \\
\hline TX & Bull Creek & Eurus & 180.00 & $\$ 91,390,497$ & $\$ 1,692$ & Mitsubishi & $32.8 \%$ \\
\hline TX & Gulf Wind & Pattern Energy & 283.20 & $\$ 178,004,264$ & $\$ 2,095$ & Mitsubishi & $36.6 \%$ \\
\hline TX & Inadale & E.On & 197.00 & $\$ 94,163,024$ & $\$ 1,593$ & Mitsubishi & $35.7 \%$ \\
\hline TX & Panther Creek III & E.On & 199.50 & $\$ 107,636,863$ & $\$ 1,798$ & GE & $38.7 \%$ \\
\hline TX & Peñascal & Iberdrola & 201.60 & $\$ 114,071,646$ & $\$ 1,886$ & Mitsubishi & $38.7 \%$ \\
\hline TX & Pyron & E.On & 249.00 & $\$ 121,903,306$ & $\$ 1,632$ & GE & $40.7 \%$ \\
\hline TX & Sunray & Valero & 40.50 & $\$ 26,246,825$ & $\$ 2,160$ & GE & $45.0 \%$ \\
\hline WA & Wild Horse & Puget Sound Energy & 44.00 & $\$ 28,674,664$ & $\$ 2,172$ & Vestas & $23.8 \%$ \\
\hline WA & Windy Flats & Cannon Power & 29.90 & $\$ 19,367,629$ & $\$ 2,159$ & Siemens & $30.2 \%$ \\
\hline & & Total: & $3,891.75$ & $\$ 2,225,671,487$ & $\$ 1,906$ & & $34.4 \%$ \\
\hline
\end{tabular}

calculate the average basis for fuel cells, because Section 1603 grants to fuel cells are capped at $\$ 1500$ per half $\mathrm{kW}$, and in some cases that cap was binding. Likewise, the basis of geothermal heat pumps and solar heat and hot water systems cannot be expressed in $\$ / \mathrm{kW}$ terms, and so are omitted from Table 1 . The rules pertaining to what project costs should and should not be included in the grant basis are somewhat involved, but a general rule of thumb is that any cost that can be depreciated or amortized can be included in the basis. As such, the basis should always be less than total installed project costs, with the difference between the two depending on the technology (for wind projects, the basis is likely to be as high as $95 \%$ of total installed project costs). Capacity factor is simply a measure of how much electricity a project generates on an annual basis relative to how much it could possibly generate if it were operating at full rated capacity in all hours of the year. 
Because large wind power projects have captured the majority of all grant dollars to date, ${ }^{7}$ much of the rest of this evaluation focuses exclusively on these large wind power projects (and to a lesser extent, geothermal electric projects, which rank a distant second). Along these lines, Table 2 provides more details on each of the 40 grants awarded to large wind power projects as of March 1, 2010. Individual project size ranges from 0.6 MW to $283.2 \mathrm{MW}$. The $\$ / \mathrm{kW}$ grant basis ranges from a low of $\$ 1,557 / \mathrm{kW}$ to a high of $\$ 3,448 / \mathrm{kW}$ (with only the two single-turbine $0.6 \mathrm{MW}$ projects in Massachusetts exceeding $\$ 3,000 / \mathrm{kW}) .{ }^{8}$ Estimated capacity factors, which are based solely on expectations of annual generation as self-reported on the Section 1603 grant application, range from $18.7 \%$ (again, for one of the 0.6 MW turbines in Massachusetts) to 45.0\%. A dozen different wind turbine manufacturers, 22 different project sponsors, and 19 different states are represented in the list of grant awardees.

In addition to the large wind power grants shown in Table 2, indications from the U.S. Treasury are that another 31 large wind power projects that were installed in 2009 had applied for, but had not yet been awarded, Section 1603 grants as of March 1, 2010. These 31 projects total 2,311 MW of capacity, bringing the aggregate capacity of 2009 wind power projects that have applied for the grant to more than 6,200 MW (3,892 MW awarded plus 2,311 MW pending), or 64\% of all 2009 wind power capacity that was eligible for the grant. ${ }^{9}$ Because projects have until September 30, 2011 to apply for the grant, it is possible that additional 2009 wind power projects will apply for the grant at a later date, in which case the $64 \%$ figure would increase as the program progresses. Any such growth is likely to be modest, however, because most eligible 2009 wind power projects have presumably already decided either to apply for the grant or to claim the PTC or ITC.

Table 3 provides similar details for the four new geothermal electric projects that had received Section 1603 grants as of March 1, 2010. A fifth project built in 2009 - Ormat's 50 MW North Brawley project in California - also plans to apply for the grant once it completes improvements to fix an operational issue (Ormat Technologies, 2010). Thus, at least five of the six geothermal electric plants brought online in 2009 have elected or plan to elect the grant; the sixth 2009 project - a small $(280 \mathrm{~kW})$ project at the Oregon Institute of Technology (Gawell and Blodgett, 2009) - is presumably ineligible for either the grant or the PTC (because it is owned by a taxexempt public university).

\footnotetext{
${ }^{7}$ There are several reasons that wind power projects have dominated the grant program - at least in dollar terms - to date: (1) wind is arguably the most economical of the technologies eligible for Section 1603 grants; (2) as a result, a large amount of wind power was already under development, or even in construction, in early 2009 when the grant program was enacted; (3) wind projects are often significantly larger (in capacity, and therefore dollar, terms) than projects involving most other eligible technologies; and (4) wind arguably receives more value from the $30 \%$ grant than does solar (for example), given that solar previously had access to the $30 \%$ ITC, whereas wind could only access the PTC. Some of these reasons are explored later in this article.

${ }^{8}$ Assuming that the basis used to calculate the size of the grant equals $95 \%$ of installed project costs, the average grant basis among wind projects that have received Section 1603 grants (i.e., \$1,906/kW) as well as the range in their basis (i.e., from $\$ 1,557 / \mathrm{kW}$ to $\$ 3,448 / \mathrm{kW}$ ) are broadly consistent with installed wind project costs in both 2008 and 2009, as reported in Wiser and Bolinger (2010, 2009).

${ }^{9}$ Broadly speaking, only those projects that would otherwise have been eligible for the PTC or ITC are eligible for the grant. Thus, projects owned by tax-exempt entities, such as municipalities, publicly owned electric utilities, rural electric cooperatives, non-profit educational institutions, or other governmental entities are not considered to be eligible for the grant.
} 
Table 3. Details of Geothermal Electric Projects Awarded Grants as of March 1, 2010

\begin{tabular}{|c|c|c|c|c|c|c|}
\hline State & $\begin{array}{c}\text { Project } \\
\text { Name }\end{array}$ & $\begin{array}{c}\text { Sponsor } \\
\text { Name }\end{array}$ & $\begin{array}{c}\text { Capacity } \\
\text { Supported by } \\
\text { Grant (MW) }\end{array}$ & $\begin{array}{c}\text { Grant } \\
\text { Size } \\
(\$)\end{array}$ & $\begin{array}{c}\text { Grant } \\
\text { Basis } \\
(\$ / k W)\end{array}$ & $\begin{array}{c}\text { Estimated } \\
\text { Capacity } \\
\text { Factor }\end{array}$ \\
\hline NV & Salt Wells & Enel & 18.6 & $\$ 21,196,478$ & $\$ 3,799$ & $71.1 \%$ \\
\hline NV & Stillwater & Enel & 47.3 & $\$ 40,324,394$ & $\$ 2,842$ & $66.8 \%$ \\
\hline NV & Blue Mountain & Nevada Geothermal Power & 49.5 & $\$ 57,872,513$ & $\$ 3,897$ & $78.4 \%$ \\
\hline UT & Thermo 1 & Raser & 10.0 & $\$ 32,990,089$ & $\$ 10,997$ & $95.0 \%$ \\
\hline \multicolumn{2}{|r|}{ Total: } & $\mathbf{1 2 5 . 4}$ & $\mathbf{\$ 1 5 2 , 3 8 3 , 4 7 4}$ & $\mathbf{\$ 4 , 0 5 1}$ & $\mathbf{7 4 . 2 \%}$ \\
\hline
\end{tabular}

In summary, the Section 1603 grant program has been heavily used by the wind and geothermal energy sectors: as of March 1, 2010, 64\% of all 2009 large wind power capacity and 100\% of all 2009 geothermal electric capacity that was eligible for the grant had elected (or, in the case of one geothermal project, had signaled an intent to elect) the grant rather than the PTC or ITC. Similar ratios are not currently available for other technologies, because information on pending grant applications for technologies other than large wind and geothermal electric was not provided. Nevertheless, based on the grant awards issued through March 1 (and shown in Table 1) and estimates of new capacity installed in 2009, the following conclusions can be reached about the four-next-largest recipients of grant dollars at that time:

- Solar photovoltaic (“PV"): Roughly $50 \mathrm{MW}$ of the estimated $429 \mathrm{MW}$ of PV installed in the U.S. in 2009 (SEIA 2010) had been awarded grants as of March 1, 2010. The nameplate capacity of individual PV projects that have received grants has varied widely, ranging from 700 Watts up to $25 \mathrm{MW}$.

- Open-loop biomass: It appears as if the vast majority of (and perhaps all) grant-eligible biomass projects built in 2009 elected the grant ( 130 MW). This is no surprise, because open-loop biomass is only eligible for $50 \%$ of the PTC's full value, but is eligible for the full $30 \%$ cash grant (i.e., the grant is likely to be worth considerably more than the PTC to openloop biomass projects).

- Solar-thermal electric: It appears that all solar-thermal electric capacity built in 2009 has elected the grant.

- Landfill gas: About 20.5 MW of the estimated 154 MW of landfill gas installed in the U.S. in 2009 had been awarded grants as of March 1.

All told, these six technologies account for $99.5 \%$ of all Section 1603 grant dollars awarded as of March 1, 2010. 


\section{Estimating the Impact of Section 1603 Grants on Large Wind Power Deployment in 2009}

Section 2 established that the Section 1603 grant program has been heavily subscribed by renewable power project developers and investors. Popularity does not necessarily imply need, however, and a relevant question for the purpose of this evaluation is to what extent the grant program had a positive impact on renewable power capacity additions in 2009. In other words, how much of the renewable power capacity built in 2009 that has selected the grant would, or would not, have been built under the PTC or ITC if the grant program did not exist?

This section seeks to answer this question - focusing entirely on wind power - by using two different and somewhat complementary approaches. First, the actual amount of large wind power capacity installed in the U.S. in 2009 is compared to earlier expectations of 2009 capacity additions. To the extent that actual additions exceeded expected additions, one might attribute at least some portion of this outperformance to the success of the grant program. Second, a qualitative review of each individual 2009 wind power project that selected the grant is conducted to determine - based on a number of factors - whether or not that project likely needed the grant, or instead likely would have been built under the PTC if the grant option did not exist. Though neither method can yield a precise estimate for the impact of the Section 1603 program, both methods can help inform that discussion.

\subsection{Method 1: Compare Actual Results to Earlier Expectations}

Largely as a result of the global financial crisis and an associated dearth of tax equity investors, widespread pessimism permeated the U.S. wind power industry heading into 2009. By the end of the year, however, a record-breaking 10,000 MW of new wind power capacity had been installed in the U.S. This is roughly $20 \%$ more wind power capacity than was installed in 2008 (the previous record year), and is 32\% to 133\% higher than expectations for 2009 wind power capacity additions as of late 2008 and/or early 2009.

Table 4 summarizes eight different projections, dating from the end of September 2008 through early May 2009, of how much wind power capacity would be installed in the U.S. in 2009. The first three projections, all from the fourth quarter of 2008, are of particular interest, since they were constructed prior to the passage of the Recovery Act in February 2009. These preRecovery Act projections for 2009 range from the EIA's Annual Energy Outlook 2009 reference case projection of 4,297 MW (EIA 2009b) to New Energy Finance's 'bullish-case' forecast of 7,600 MW (NEF 2008). 
Table 4. Forecasts of U.S. Wind Power Capacity Additions in 2009 (MW)

\begin{tabular}{|c|c|c|}
\hline Source of Projection & 2009 MW & Projection Date \\
\hline GlobalData* & 5,350 & September 30, 2008 \\
\hline New Energy Finance (NEF) & $5,880-7,600$ & October 23, 2008 \\
\hline Energy Information Administration (EIA) & 4,297 & December 9, 2008 \\
\hline BTM Consult & 6,000 & March 2009 \\
\hline New Energy Finance (NEF) & $4,900-6,800$ & April 3, 2009 \\
\hline American Wind Energy Association (AWEA) & $>5,000$ & April 13, 2009 \\
\hline Energy Information Administration (EIA) & 4,404 & April 14, 2009 \\
\hline Emerging Energy Research (EER) & 6,500 & May 5, 2009 \\
\hline Actual (per AWEA) & 9,997 & as of March 8, 2010 \\
\hline
\end{tabular}

Interestingly, the five projections made after the passage of the Recovery Act fall into a similar, though slightly tighter, range. In other words, somewhat counter-intuitively, projections of 2009 wind power additions made after the passage of the Recovery Act are not significantly different from those made earlier - even by the same forecasting entity. For example, the revised Annual Energy Outlook 2009 service report updated in April 2009 to reflect passage of the Recovery Act (EIA 2009a) projects only $107 \mathrm{MW}$ of additional wind power installations in 2009 as a result of the Recovery Act (i.e., 4,404 MW instead of 4,297 MW). More striking, New Energy Finance's post-Recovery Act projection of wind power additions for 2009 (NEF 2009b) actually decreased by 800-1000 MW (i.e., 4,900-6,800 MW instead of 5,880-7,600 MW). New Energy Finance attributed its less-ambitious post-Recovery Act forecast to worsening financial conditions since its October 23, 2008 projection. It is also apparent that most forecasting entities expected the Section 1603 grant program to take longer to implement than it actually did, thereby dampening the expected impact of the program on 2009 wind power additions.

Regardless of when each forecast was generated, it is clear from Table 4 that none of the major forecasting entities predicted anything close to the actual outcome of roughly 10,000 MW of new wind power installations in 2009. Specifically, among all eight forecasts listed in Table 4, projections for 2009 ranged from a low of 4,297 MW (EIA 2009b) to a high of 7,600 MW (NEF 2008), while the actual amount of wind power installed exceeded these two outer bounds by 5,700 MW (133\%) and 2,400 MW (32\%), respectively (i.e., by a mid-point of about 4,000 MW, or $67 \%)$.

Some of this outperformance relative to expectations can likely be attributed to the impact of the Section 1603 grant program. Estimating just how much, though, is difficult, for at least two reasons. First, the accuracy of installation forecasts, such as those presented in Table 4, has been wanting historically. Second, and more importantly, underlying market conditions were not static throughout the year: for example, financial conditions gradually improved over the course of 2009 (independently of the grant program), presumably also enabling some unexpected wind power capacity additions. On the other hand, wholesale power prices continued to fall into early 2009 and remained low throughout the year, thereby eroding the competitiveness of wind power and, in turn, making the outperformance relative to expectations even more noteworthy. For lack of a more-sophisticated approach, taking the mid-point of the range of outperformance - i.e., about 4,000 MW - and assuming that roughly half of it may be attributable to the cash grant 
program (with the other half attributable to improving financial conditions, projection inaccuracy, and other factors), yields a crude estimate that the grant program may have been directly responsible for about 2,000 MW of the wind power capacity built during 2009 .

\subsection{Method 2: Review Each Project That Has Elected the Grant}

Another way to gauge how much of the 2009 wind power capacity additions might be attributable to the Section 1603 grant program is to review each individual project that selected the grant, taking note of who owns the project and when in 2009 the project was built. Knowing who owns the project - and whether that owner likely has the capacity to absorb tax benefits on its own, or instead has historically turned to third-party tax equity investors for that purpose can shed some light on how dependent the project likely is on the grant. Similarly, knowing when in 2009 - i.e., before or after the enactment or implementation of the Section 1603 program - the project achieved commercial operations can shed light on this same question. For example, if the bulk of 2009 wind power capacity that selected the grant was installed in the second half of the year - i.e., after the Section 1603 program was underway - that might suggest more of an influence than if the reverse were true.

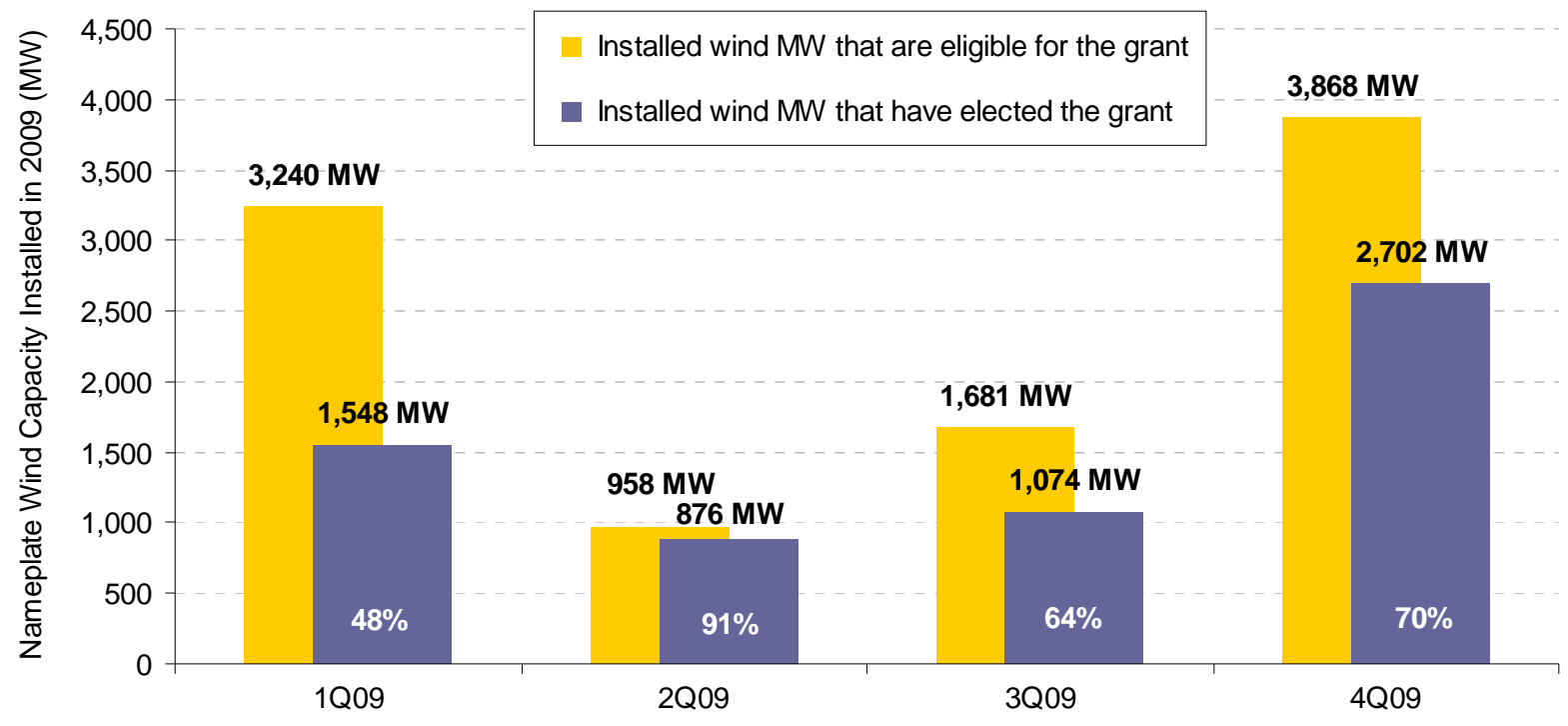

Figure 1. Quarterly Breakdown of Wind Power Capacity Installed in 2009

Section 2 earlier demonstrated that at least 6,200 MW, or 64\% of all 2009 wind power capacity that was eligible for the grant, had applied for the grant as of March 1, 2010. Figure 1 breaks down the grant-eligible wind power capacity, as well as grant-eligible capacity that elected the grant $(6,200 \mathrm{MW})$, by the quarter in which the associated projects achieved commercial operation. $^{10}$

The sizable amount of grant-eligible wind power capacity installed in 1Q09 - i.e., 3,240 MW - is largely due to spillover from projects that had previously been targeting an end-of-2008 inservice date. Once the PTC was extended through 2009 as part of The Energy Improvement and

\footnotetext{
${ }^{10}$ The quarter in which a project achieved commercial operation is based on information provided by AWEA (2010c).
} 
Extension Act in October 2008, some portion of these projects relaxed their construction schedules and lapsed into 1Q09. This lapse made these projects eligible for the Section 1603 grant program and, as shown in Figure 1, nearly half (48\% or 1,548 MW) of the 1Q09 granteligible capacity elected the grant. Given that the Recovery Act did not become law until midFebruary, however, presumably all of the 1Q09 projects that elected the grant can be considered "free riders" in the sense that they would have been built under the PTC if the Section 1603 grant program did not exist.

The same can likely be said for the $876 \mathrm{MW}$ of large wind power capacity that elected the grant in 2Q09. In order for a wind power project to have achieved commercial operations in 2Q09, it would have needed to start construction well before that - if not in 2008, then at least in 1Q09, and in most cases prior to the passage of the Recovery Act in mid-February. Furthermore, Treasury did not issue formal guidance on the program, or begin accepting applications, until July 2009 - i.e., after 2Q09 had ended. As such, it is likely that most or all of the 2Q09 wind power capacity that selected the grant would have come on line in 2Q09 even absent the Treasury grant program.

A closer examination of the seven individual 2Q09 projects (totaling $876 \mathrm{MW}$ ) that elected the grant supports this notion:

- Four of these projects, totaling $610 \mathrm{MW}$, are owned by Iberdrola, which historically has not had sufficient tax credit appetite to use the PTC and accelerated depreciation on its own (Chadbourne \& Parke 2008). As such, one might initially consider the grant to be a potentially driving influence behind these projects. However, all four of these projects were generating at least some electricity prior to the passage of the Recovery Act, ${ }^{11}$ suggesting that they were already well under construction before the grant program was codified. Also telling is that Iberdrola chose not to apply for the grant for a fifth project also built in 2Q09, suggesting that economic value, rather than need, was likely the primary consideration surrounding the choice of incentive for all five projects.

- The three other projects, totaling 267 MW, are owned by John Deere, Edison Mission, and Duke Energy. At least historically, these three developers have had sufficient tax credit appetite to be able to use the PTC and accelerated depreciation on their own (i.e., without turning to third-party tax equity investors), suggesting that selection of the grant was likely motivated more by economic value than by absolute need. The fact that John Deere elected the PTC for two other projects (totaling $20 \mathrm{MW}$ ) that it also built in 2Q09 supports this notion.

Although most, if not all, of the wind power projects that were completed in the first half of 2009 and that elected the grant likely did not strictly need the grant, the same cannot be said for projects that came online in the second half of the year. An examination of individual wind power projects placed in service in 3Q09 and 4Q09 suggests that a sizable number may still have been placed in service in 2009 even without the grant program, but that many others likely owe their 2009 in-service date at least in part to the program:

- In 3Q09, at least $467 \mathrm{MW}$, or $44 \%$ of the 1,074 MW of wind power capacity selecting the grant from that quarter, would likely have been built under the PTC if the grant did not exist.

\footnotetext{
${ }^{11}$ Based on data obtained from FERC Electronic Quarterly Reports (http://www.ferc.gov/docs-filing/eqr.asp) and Form EIA-923 (http://www.eia.doe.gov/cneaf/electricity/page/eia906_920.html).
} 
This 467 MW includes projects owned by NextEra, John Deere, and Edison Mission Energy - each of which has historically been able to absorb the PTC and accelerated depreciation on its own - as well as two other projects (owned by others) that were generating at least some power prior to the passage of the Recovery Act. The remaining $607 \mathrm{MW}$ of wind power capacity that achieved commercial operations in the third quarter may have been motivated in part by the grant program.

- In 4Q09, at least $875 \mathrm{MW}$, or 32\% of the 2,702 MW of capacity selecting the grant from that quarter, would likely have been built under the PTC if the grant did not exist. This $875 \mathrm{MW}$ consists entirely of projects owned by NextEra, Otter Tail Power, NRG Energy, and Puget Sound Energy - all entities with tax credit appetite. The remaining 1,827 MW of wind power capacity that achieved commercial operations in the fourth quarter may have been motivated in part by the grant program.

It is important to recognize that these estimates, particularly in the second half of 2009, are just that - estimates - and the true numbers could be higher or lower. For example, the estimates assume that developers without much U.S. tax credit appetite are dependent on the grant (unless there is some reason to believe otherwise, such as their projects generating power prior to the passage of the Recovery Act). In reality, though, it is likely that most of these developers would have proceeded with at least some of their projects under the PTC, if the grant did not exist. ${ }^{12}$ On the other hand, the estimates also assume that all projects owned by developers with tax credit appetite would have come on line even absent the Section 1603 program. It is possible, however, that in some instances the direct and/or indirect economic value that the Section 1603 program provides to project investors (described later in Sections 5.2 and 5.3) may have been both necessary and sufficient to motivate a particular project, regardless of tax appetite considerations. ${ }^{13}$ On balance, then, the estimates presented above of projects that may have proceeded without the Section 1603 grant may be either too high or too low.

With those caveats, over the entire year the estimates described above sum to roughly 3,766 MW of wind power that elected the grant without necessarily needing it, and 2,433 MW of wind power that could conceivably be dependent on the grant. The 2,433 MW estimate of grantdriven capacity arrived at using this method is not too dissimilar from the roughly 2,000 MW estimate derived using the cruder method described earlier in Section 3.1.

\footnotetext{
${ }^{12}$ For example, Broehl (2010) reports Iberdrola as saying that, if the grants did not exist, it would have built only about $50 \%$ of the wind capacity that it actually did build in the US in 2009. Although our review of Iberdrola's projects pegs this percentage at $83 \%$ rather than $50 \%$ (based purely on when the projects began generating at least some power), the broader point is that developers - even those without tax credit appetite - freely acknowledge that they would have proceeded with at least some projects even without the grant.

${ }^{13}$ In other words, it is possible that one or more projects that were uneconomical under the PTC became economical under the grant, in which case even if the developer was not dependent on the grant from a tax equity perspective (i.e., it would have been able to efficiently use the PTC on its own), it was nevertheless dependent on the grant for the extra direct or indirect value that it provides.
} 


\section{Estimate of Wind Power Sector Jobs Supported by the Section 1603 Program}

One of the justifications for implementing the Section 1603 grant program as part of the Recovery Act was to preserve jobs within the renewable energy sector that might otherwise be lost due to the pervasive lack of finance. ${ }^{14}$ As such, another relevant question for the purposes of this evaluation is to what extent the Section 1603 program has achieved this objective.

An estimate of the number of jobs supported can be developed - for large wind power grant applicants only - by using a national version of the Jobs and Economic Development Impact (“JEDI”) model, developed by MRG \& Associates under contract to the National Renewable Energy Laboratory ("NREL"). ${ }^{15}$ The JEDI model is an "input-output" model tailored specifically to large wind power projects, and is capable of estimating the number of jobs supported by project development and onsite labor during construction and operations, interindustry spending along the supply chain, and induced spending. ${ }^{16}$ The model uses economic multipliers derived from IMPLAN data using the IMPLAN Professional ${ }^{\mathrm{TM}}$ Version 2.0 Social Accounting \& Impact Analysis Software. More information on the JEDI model can be found at the following web link: http://www.nrel.gov/analysis/jedi/.

It is important to recognize that NREL's JEDI model, as used here, provides estimates of gross jobs associated with wind power development. The JEDI model does not account for the fact that at least some of the estimated jobs will be filled by workers who leave existing jobs, meaning that job gains in the wind power sector might come at the expense of job losses elsewhere. Related, the model does not consider that an increase in wind-powered generation will result in a decrease in other types of generation, leading to job losses at non-wind power plants and the suppliers that serve those plants. Finally, the model does not consider the fact that electricity and tax expenditures may change under increased wind energy deployment, potentially yielding job losses or gains in the larger economy. The jobs estimates reported by the JEDI model should, therefore, be considered gross, rather than net, jobs, and should be considered only a partial response to questions about the impact of the Section 1603 program on domestic jobs.

At the most basic level, the national JEDI model only requires project-specific inputs for the following parameters: year of construction and dollar year (both 2009); project location (the United States); project capacity in MW; wind turbine capacity in $\mathrm{kW}$; and installed project cost in $\$ / \mathrm{kW}$. Each of these variables is available or can be readily estimated. Project and individual turbine capacity for all large wind power grant applicants is available. For each of the 40 projects that have been awarded grants, installed project costs can be estimated by dividing the

\footnotetext{
${ }^{14}$ The first item listed in the "Statement of Purposes" in Section 3 of the Recovery Act is "To preserve and create jobs and promote economic recovery."

${ }^{15}$ Apart from jobs, the JEDI model can also estimate the local economic impacts of wind power development (e.g., land lease payments, property tax revenue, etc.). This section, however, focuses exclusively on jobs. Also note that this national version of the JEDI model - arguably most appropriate for the multi-project, multi-state analysis conducted here - is different from the state-based version of the model that is available on NREL's web site.

${ }^{16}$ Induced jobs are created or supported by the general increase in spending that accompanies growth in household income as both onsite and supply chain jobs are added. Onsite jobs are easier to estimate and measure than are supply chain or manufacturing jobs, while induced jobs are inherently more difficult to estimate or measure than either onsite or supply chain jobs.
} 
size of the grant by $30 \%$ to arrive at the "grant basis," and then dividing that basis by $95 \%$ (reflecting an assumption that the grant basis will, on average, be roughly 95\% of total installed project costs). For each of the 31 pending large wind power projects that have applied for, but not yet received, a grant, one can simply assume that installed project costs will equal the capacity-weighted average installed cost (derived as described in the previous sentence) of the 40 projects that have already been awarded grants - i.e., roughly $\$ 2,000 / \mathrm{kW}$.

For all other required inputs - e.g., more-detailed installed cost breakdowns, operations and maintenance ("O\&M") costs, financial parameters, the proportion of materials and labor that are sourced locally ("local share”), etc. - the JEDI model provides representative 'default' values (each of which can be modified by the user) that are based on interviews with wind power project developers and others in the industry. For the purposes of this analysis, modifications were made only to the "local share" default assumptions, as follows: 25\% of turbines (excluding blades and towers) are assumed to be manufactured domestically, as are $70 \%$ of blades and towers. These three items - blades, towers, and the remainder of the turbine - account for roughly two-thirds of total installed project costs. ${ }^{17}$ All other installation and operational costs, including those associated with transportation, balance of plant, O\&M materials, and all (nonturbine) labor, are assumed to have a 100\% local share. In aggregate, these "local share" assumptions result in a project that has an overall domestic content of about $60 \%$, which is roughly consistent with estimates provided by the U.S. International Trade Commission (David 2009), Kirkegaard et al. (2009), and AWEA (2010b, 2009).

Based on these assumptions, Table 5 presents gross domestic job estimates from NREL's JEDI model, broken out among those projects that have already been awarded grants, those that have applied for but not yet received grants, and the total of these two categories. Focusing just on the total, the JEDI model estimates that these 71 wind power projects totaling more than 6,200 MW have supported roughly 133,000 short-term full-time equivalent ("FTE") gross job-years in the United States during the construction/manufacturing phase. It is important to emphasize that many of these construction-phase jobs are short-term in nature, and so are presented in terms of the number of FTE jobs in a single year - i.e., "job years". ${ }^{18}$ During the operational phase, the JEDI model estimates that these 71 wind power projects may support nearly 10,000 FTE gross jobs that will last for as long as the project does (generally assumed to be 20 to 30 years). Because the "local share" assumptions were pre-specified (as discussed above, leading to roughly $60 \%$ domestic content overall), all of the construction and operational jobs shown in Table 5 can be thought of as domestic jobs within the United States. Finally, as is evident from the table, onsite jobs represent the minority of the total jobs estimated by the JEDI model; the broader supply chain and induced jobs associated with wind power projects are found to dominate the totals.

\footnotetext{
${ }^{17}$ The "local share" assumptions for these three items are based upon estimates from the U.S. International Trade Commission (David 2009), Kirkegaard et al. (2009), and AWEA (2010b, 2009) regarding total domestic content of wind projects in the U.S., combined with anecdotal (and seemingly logical) estimates of the relative domestic content of blades, towers, and nacelles. Blades and towers are relatively expensive to ship and relatively easy to manufacture locally, compared to nacelles, which contain each turbine’s “vital organs” (e.g., gearbox, generator, electronics) and are somewhat-easier to ship from overseas.

${ }^{18}$ In other words, if two people each work on a project for six months, it is reported as one FTE (or one job-year). Similarly, if one person works on a project for two years, it is reported as two FTEs (or two job-years).
} 
Table 5. Gross Job Estimates from the JEDI Model (assuming 60\% overall domestic content)

\begin{tabular}{|c|r|r|r|r|}
\hline & & $\begin{array}{c}\text { Awarded } \\
\text { Projects }\end{array}$ & $\begin{array}{c}\text { Pending } \\
\text { Projects }\end{array}$ & Total \\
\hline & Number of Projects & 40 & 31 & 71 \\
& Aggregate Capacity (MW) & $3,892 \mathrm{MW}$ & $2,311 \mathrm{MW}$ & $6,202 \mathrm{MW}$ \\
\hline Construction Phase & Project development and onsite labor impacts & 4,200 & 2,451 & 6,651 \\
(Gross short-term jobs: & Turbine and supply chain impacts & 42,269 & 25,013 & 67,282 \\
FTE for 1 year) & $\underline{\text { Induced impacts }}$ & $\underline{37,259}$ & $\underline{22,036}$ & $\underline{59,296}$ \\
\hline $\begin{array}{c}\text { Operational Phase } \\
\text { (Gross long-term jobs: }\end{array}$ & Total Construction Phase: & $\mathbf{8 3 , 7 2 8}$ & $\mathbf{4 9 , 5 0 0}$ & $\mathbf{1 3 3 , 2 2 8}$ \\
FTE for 20-30 years) & Onsite labor impacts & 227 & 130 & 357 \\
\hline
\end{tabular}

It should be re-emphasized that these estimates are of gross jobs, and are inherently uncertain. The estimates of gross jobs reported here for wind power deployment differ somewhat (on a perMW basis) from the findings of selected studies summarized in Wei et al. (2010). Moreover, the estimates presented here are not entirely comparable with, but are nevertheless seemingly considerably higher than, estimates from the Council of Economic Advisers (2010) on the employment impacts of the Recovery Act (not just the Section 1603 program) on the broader renewable energy sector. As such, though JEDI-estimated gross jobs impacts are reported here, it is important to recognize that not only are these estimates focused on gross (not net) jobs, but that the estimates themselves are inherently uncertain. Moreover, the level of uncertainty increases as one moves from onsite to supply chain and then to induced job estimates. ${ }^{19}$

The numbers presented in Table 5 pertain to all large wind power projects built in 2009 that have elected the Section 1603 cash grant in lieu of the ITC or PTC. As discussed at length in Section 3 , however, a significant portion of these projects would likely have been built under the PTC if the Section 1603 grant program did not exist. The jobs numbers presented in Table 5 cannot, therefore, be entirely attributed to the Section 1603 cash grant program.

If one assumes, however, from the findings in Section 3, that roughly 2,400 MW of the total 6,200 MW of wind power capacity that have elected the grant depend on the grant for viability (i.e., would not have been built under the PTC), then one can get a rough estimate of the gross jobs impact directly attributable to the Section 1603 cash grant program simply by multiplying the numbers in the final column of Table 5 by 39\% (i.e., 2,400 MW / 6,200 MW). Doing so yields approximately 51,600 gross short-term job-years during the construction phase, and 3,860 gross long-term jobs during the operational phase. These estimated jobs might be directly attributed to the Section 1603 program, under the assumptions made here.

\footnotetext{
${ }^{19}$ The Council of Economic Advisers (2010) analysis, for example, estimates that roughly two-thirds of the jobs driven by the Recovery Act's support for renewable energy are either direct or indirect, with the remaining one-third representing induced jobs. In contrast, the JEDI results presented here estimate that induced jobs account for $45 \%$ of all job-years during the construction phase, and $60 \%$ of all jobs during the operational phase.
} 


\section{Analysis of the Economic Value of the Section 1603 Grant to Renewable Project Owners}

In addition to near-term job preservation and creation, another goal of the Recovery Act is to provide long-term economic benefits by investing in environmental protection and other infrastructure. ${ }^{20}$ A related goal specifically for the Section 1603 program is to help capture "the long-term benefit of expanding the use of clean and renewable energy and decreasing our dependency on non-renewable energy sources” (U.S. Department of the Treasury 2009).

A principal way in which the Section 1603 program facilitates the achievement of these goals is by providing economic value to renewable energy projects. The grant's economic value, relative to the PTC or even the $30 \%$ ITC, can be broken down into three non-overlapping components: the financing advantage that it provides when tax equity is scarce and/or expensive, its "direct" or "face" value, and its "indirect" or "ancillary" benefits. In combination, these benefits of the grant program help explain the estimate provided earlier of more than 2,000 MW of wind power capacity added in 2009 that might not otherwise have come online that year. This section briefly analyzes each of these value components.

\subsection{Financing Advantage}

As noted earlier, a primary goal of Congress in enacting Section 1603 of the Recovery Act was to reduce the market's dependence on third-party tax equity investors, in the hopes that this would enable renewable power projects to progress towards construction, even in the absence of such investors. Just prior to the passage of the Recovery Act, the unfolding financial crisis had limited the supply of this historically important source of capital for the renewable power market, leaving a considerable financing gap for many projects.

Specifically, after hitting a peak of more than $\$ 5$ billion in 2007, the amount of third-party tax equity invested in wind power projects actually declined somewhat in 2008 (Eber 2009, Hudson Clean Energy Partners 2009), despite the fact that the amount of wind power capacity installed in 2008 was $60 \%$ higher than the amount installed in 2007. By the end of 2008, with the financial crisis in full swing, only a handful of tax equity investors remained in the market - down significantly from a group that had previously numbered in the teens (Chadbourne \& Parke 2008). Moreover, those few investors left in the market were able to charge considerably more for the use of their tax base, putting at risk the economic viability of some fraction of the planned renewable energy projects.

By the end of 2008, the cost of tax equity had risen enough - reportedly by 200 basis points or more (Chadbourne \& Parke 2009, 2008) - that some developers began to talk about "selfsheltering" their projects' tax benefits rather than paying tax equity investors to monetize them (Chadbourne \& Parke 2008). ${ }^{21}$ At that time, Iberdrola estimated that, for an average wind power

\footnotetext{
${ }^{20}$ The fourth item listed in the "Statement of Purposes" in Section 3 of the Recovery Act is "To invest in transportation, environmental protection, and other infrastructure that will provide long-term economic benefits."

${ }^{21}$ A wind project owner that does not have any other taxable income (apart from that generated by the project itself) can "self-shelter" the project's tax benefits (accelerated depreciation deductions and PTCs) by carrying them forward in time until they can be fully applied against the project's own taxable income. In general, at today's electricity sales prices, it might take roughly 12 years for a self-sheltered wind project to fully work through net operating losses (i.e., from depreciation deductions), after which it can begin to apply the PTC against its tax
} 
project, self-sheltering the PTC and depreciation would reduce its internal rate of return ("IRR”) by about 300 basis points relative to what it would otherwise be if it could efficiently use all tax benefits in the year they were generated (Chadbourne \& Parke 2008). The mere fact that Iberdrola considered self-sheltering suggests that the cost of tax equity was also approaching levels that would reduce IRRs by 300 basis points, ${ }^{22}$ and thereby provides some indication of the hostile financing environment from which the Section 1603 grant program emerged.

Under the Section 1603 grant program, self-sheltering looks considerably more attractive than it did under the PTC. Instead of having to wait until after the project's twelfth year (i.e., assuming that it takes an average project 12 years to work through net operating losses from depreciation deductions) to begin applying the PTC, the cash grant can be used as early as 60 days after commencing commercial operations. This time-value advantage is significant: assuming a 10\% nominal discount rate, it equates to roughly $14 \%$ of installed project costs (on a present value basis), which reclaims more than half of the $24 \%$ of installed project costs that are forfeited by self-sheltering both the PTC and depreciation (the remaining 10\% loss is due to the cost of selfsheltering depreciation alone). If a loss of $24 \%$ of installed project costs corresponds to a roughly 300 basis point loss of IRR for an average Iberdrola wind power project, then selfsheltering under the grant rather than the PTC can be thought of as recouping roughly 175 basis points of that lost IRR. In other words, the self-sheltering penalty under the grant comes to roughly 125 basis points (from self-sheltering depreciation), rather than 300 basis points under the PTC (from self-sheltering both depreciation and the PTC).

Although the cost of tax equity appears to have declined somewhat since late 2008 - e.g., Chadbourne \& Parke (2010a, 2010b) estimates that unlevered tax equity yields currently range from $8 \%$ to $9 \%$ - tax equity may still have difficulty competing with a 125 basis point selfsheltering penalty under the grant. ${ }^{23}$ For this reason, as well as the general shortage of tax equity that still exists, many wind power projects that have elected the Section 1603 cash grant have reportedly decided to self-shelter (Chadbourne \& Parke 2010a, 2010b; Feo 2010). As estimated in the previous paragraph, the financing advantage of the grant (relative to the PTC) in these situations could conceivably be as high as 175 basis points, or 14\% of installed project costs. That number likely represents an upper bound, however, for two reasons: (1) many wind power

liability (Chadbourne \& Parke 2008). Though a feasible way to eventually use all of a wind project's tax benefits, self-sheltering negatively impacts the time value of these benefits, compared to the optimal situation in which most of the project is depreciated in the first 5 years, and in which the PTC is used as generated over the first 10 years. For this reason, most developers in this situation have, at least historically, still found it advantageous to finance their projects using third-party tax equity that is capable of monetizing tax benefits as they are generated - even though such tax equity is more expensive than term debt. As the cost of tax equity spiked towards the end of 2008, however, it became questionable whether the time-value savings justified the sharply higher cost of tax equity, leading some developers to consider self-sheltering the tax benefits on their own.

${ }^{22}$ Based on a back-of-the-envelope estimate similar to that presented in Chadbourne \& Parke (2008), the numbers also seem to bear this out. If one assumes that, at that time, the cost of tax equity had risen to around $10 \%$ (on an after-tax, unleveraged basis) and debt interest rates were around 6.2\% (NEF 2009a), then tax equity required a premium of 600 basis points above the $4 \%$ after-tax cost of debt. With tax equity supplying roughly $50 \%$ of project capital at that time (Chadbourne \& Parke 2008, 2010b), tax equity essentially cost the project 300 basis points more than would project-level term debt. In other words, the cost of tax equity was similar to the cost of self-sheltering.

${ }^{23}$ For example, recalculating the back-of-the-envelope example laid out in the previous footnote at an 8\% (rather than 10\%) cost of tax equity still yields a 200 basis point return impairment - no longer enough to warrant selfsheltering of the PTC, but still enough to consider self-sheltering of the grant. 
project developers have at least some taxable income from other sources outside of the project itself, ${ }^{24}$ which means that their self-sheltering will be more-rapid and -efficient than assumed here; and (2) as noted above, tax equity yields have fallen somewhat from the levels that nearly triggered self-sheltering under the PTC, meaning that the baseline has shifted. ${ }^{25}$ For these reasons, the financing advantage of the grant (relative to the PTC) is estimated to be closer to 100 basis points, or around $8 \%$ of installed project costs on average.

Finally, although the discussion and analysis in this section have so far revolved around large wind power projects, the financing advantage provided by the cash grant is also applicable to smaller renewable power projects that are not large enough to attract the interest of third-party tax equity investors. For example, a $10 \mathrm{~kW}$ PV system installed on the roof of a business is too small to attract third-party tax equity, and the business may not have sufficient tax liability to use the ITC and accelerated depreciation efficiently. In this situation, carrying forward and selfsheltering the project's tax benefits may be the business's only recourse, ${ }^{26}$ and as demonstrated in this section, self-sheltering under the grant is considerably more advantageous than selfsheltering under the PTC or ITC.

\subsection{Direct or Face Value}

The previous section estimated only the financing advantages gained by virtue of the grant program. In most cases, however, the grant and PTC will also differ in terms of the amount of "direct” or "face" value provided to a project, where direct or face value refers to the "as-stated" after-tax dollar value of an incentive. For example, depending on the technology, the face value of the Section 1603 cash grant (or the ITC) equals either $30 \%$ or $10 \%$ of a project's eligible cost basis, while the face value of the PTC equals the aggregate dollar value of all PTCs earned over the full 10-year duration of the credit (starting at either \$21/MWh or \$11/MWh in 2009 and escalating with inflation thereafter).

The only variables needed to calculate the direct or face value of these two incentives are the project's eligible grant basis (for the grant) and how much electricity is generated (or expected to be generated) over a project's first ten years (for the PTC). In addition, by statute, a project's "depreciable basis" (i.e., the amount that will be depreciated for tax purposes) must be reduced by $15 \%$ (i.e., half of the $30 \%$ grant or credit) if the project chooses the cash grant (or ITC); no such adjustment is required if the project elects the PTC.

\footnotetext{
${ }^{24}$ For example, setting aside those developers that clearly have adequate tax appetite (e.g., NextEra), Iberdrola owns a New England electric utility and natural gas business (Chadbourne \& Parke 2008), Invenergy both develops and owns gas-fired generators in addition to wind projects, and other developers not commonly thought of as having tax appetite may nevertheless have ownership stakes in multiple operating wind projects that could generate at least some additional income to help facilitate self-sheltering.

${ }^{25}$ In other words, although at current yields tax equity still has difficulty competing with self-sheltering of the grant, it can now more-readily out-compete self-sheltering of the PTC, which means that the financing advantage of switching from the PTC to the grant is not as large as it once was. That said, it is worth noting that some of the decline in tax equity yields over this period could conceivably be attributed to the grant program itself, which has reduced the demand for tax equity.

${ }^{26}$ In some parts of the U.S., such a business may be able to enter into a power purchase agreement or lease arrangement (through which tax benefits are monetized in the form of lower monthly payments), rather than owning the system itself.
} 
Armed with this knowledge, one can analyze the relative face value of these incentives across a wide array of installed project cost and capacity factor combinations. ${ }^{27}$ Bolinger et al. (2009) performed such an analysis for hypothetical wind power, open-loop biomass, closed-loop biomass, geothermal, and landfill gas projects, all of which have a choice between the PTC and the ITC or cash grant. ${ }^{28}$ Figure 2 borrows from that methodology and, using a $10 \%$ nominal discount rate, applies it to the 40 large wind power projects that had been awarded grants as of March 1, 2010. ${ }^{29}$ In Figure 2, the PTC provides more face value to those projects for which the intersection of capacity factor and installed cost falls above the diagonal "break-even" line (i.e., higher capacity factor and/or lower installed cost), while the cash grant provides more face value to those projects that fall below the diagonal break-even line (i.e., lower capacity factor and/or higher installed cost).

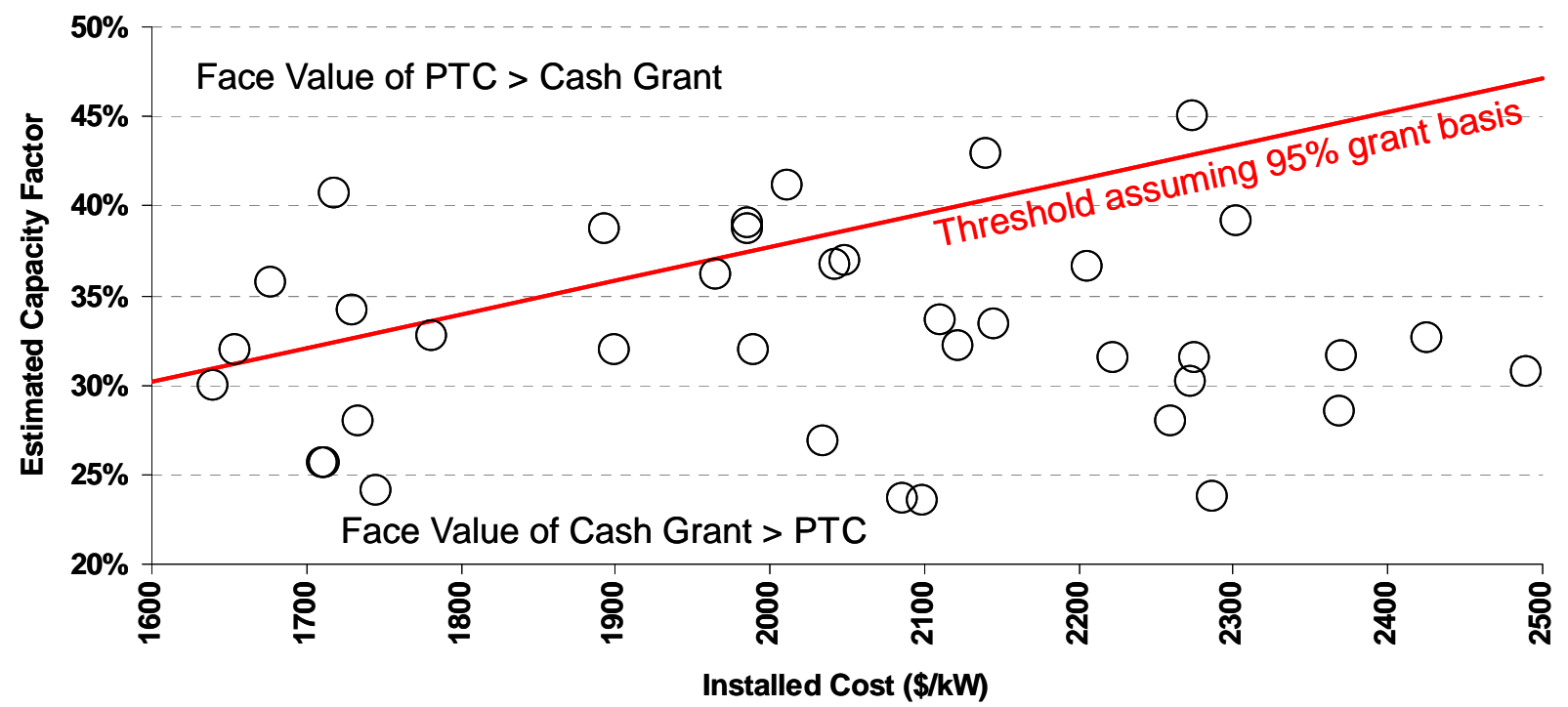

Figure 2. Relative Face Value of PTC versus Cash Grant for Large Wind Power Projects

As shown, ten of the 40 large wind power grant recipients fall above the threshold (and so would theoretically capture more face value from the PTC than they would from the grant), while 30 fall below the threshold and therefore are predicted to receive greater face value from the cash

\footnotetext{
${ }^{27}$ Because the cash grant (or ITC) is paid in the project's first year, while the PTC is earned more or less proportionally over the project's first 10 years, the results of face value analysis also depend upon the discount rate chosen (in addition to the project's grant basis and estimated capacity factor). Specifically, a higher discount rate will more-heavily discount future PTCs, making the PTC worth less on a present value basis (while not having as large of an impact on the grant). Depending upon the project's grant basis and estimated capacity factor, however, choice of discount rate may or may not be sufficient to sway the binary choice of PTC versus cash grant - i.e., all three variables matter. The face value analysis conducted in this section uses a $10 \%$ nominal discount rate; one could plausibly argue that either a higher or lower discount rate is more appropriate.

${ }^{28}$ Bolinger et al. (2009) did not evaluate solar power projects because solar already had access to the 30\% ITC prior to the Recovery Act, and by design there should be very little difference in face value between the ITC and cash grant.

${ }^{29}$ Modeling assumptions include the following: 95\% depreciable basis (90\% 5-year MACRS, 3\% 15-year MACRS, 2\% 20-year straight line); 50\% first-year bonus depreciation (since projects were built in 2009); 2009 PTC inflation adjustment factor of 1.4171; $2 \%$ inflation; 2010 first operational year; 10\% nominal discount rate; no discounting of $30 \%$ cash grant (since it can be received within 60 days of commercial operations).
} 
grant. $^{30}$ Seven of the ten projects that selected the grant even though the PTC would appear to provide superior face value are owned by three entities that are considered to not have much U.S. tax credit appetite, perhaps suggesting that in these seven cases, at least, the choice of the grant was based on the financing advantage discussed in Section 5.1. Four of these seven projects, however, were generating at least some power early enough in the year (in some cases prior to the passage of the Recovery Act) to cast doubt on this notion. An eighth project that appears to have sacrificed face value by selecting the grant is a "behind-the-meter" project (i.e., one that uses the power directly on-site) that would not have qualified for the PTC anyway (power must be sold in order to qualify for the PTC). The remaining two projects are owned by entities with presumably sufficient tax credit appetite to make efficient use of the PTC, and their election of the grant may be based on other considerations (e.g., a desire to minimize performance risk associated with the PTC, or a desire to preserve tax equity for future wind power investments once the grant program ends).

Overall, in nine of these ten cases, the estimated amount of face value forfeited by electing the grant over the PTC is rather modest (i.e., the projects fall close to the break-even threshold), perhaps suggesting that other considerations - e.g., the financing advantage discussed in Section 5.1, or one or more of the ancillary benefits of the grant described next in Section 5.3 outweighed face value. For the other 30 projects, the cash grant program is found to offer greater face value to project investors than the otherwise-available PTC, in some cases by a large margin. On a weighted-average basis, the ten projects that selected the grant even though the PTC provides greater face value forfeited an estimated $2.5 \%$ of average installed project costs, while the 30 projects for which the grant is found to provide greater face value gained roughly $4.2 \%$ of average installed project costs. Averaged across all 40 wind power projects, the grant provided superior face value to the tune of roughly $2.2 \%$ of average installed project costs on net. $^{31}$

Figure 3 shows a parallel analysis for the four geothermal projects built in 2009 that received a cash grant. $^{32}$ In this case two PTC/grant thresholds are shown: one assuming a 75\% grant basis, and the other assuming a 95\% grant basis. Bolinger et al. (2009) assumed a 75\% grant basis to account for the fact that geothermal projects are able to expense and/or deplete certain cost items for tax purposes, and those items - assumed to equal $25 \%$ of the basis - must then be removed from both the depreciable and grant basis. However, projects also have the ability to capitalize and depreciate these cost items, which may be more advantageous with a 30\% - rather than 10\% - ITC or cash grant available (because the higher basis yields a larger absolute cash grant).

\footnotetext{
${ }^{30}$ Only 38 projects are shown in Figure 1 . The remaining two - both single-turbine 0.6 MW installations - had installed costs in excess of $\$ 3,000 / \mathrm{kW}$, and are therefore off the scale of the graph (both favor the grant).

${ }^{31}$ It is worth noting that this face value estimate of $2.2 \%$ of average installed project costs would be slightly higher i.e., around $3.7 \%$ of installed project costs - if the face value analysis had instead used a 12-year straight-line depreciation schedule, as might be more appropriate under the self-sheltering scenarios described in Section 5.1. Because the depreciable basis of a project choosing the grant (or ITC) must be reduced by half the value of the incentive (i.e., by 15\%), the relative face value of the grant over the PTC increases when a less-advantageous depreciation schedule is used.

${ }^{32}$ Only three of the four projects are shown in Figure 2. The fourth had an installed cost in excess of $\$ 11,000 / \mathrm{kW}$, and therefore is off the scale of the graph (but favors the grant). A fifth geothermal project placed in service in 2009 intends to apply for a grant, but not until it finishes installing equipment needed to solve a technical problem (Ormat Technologies, 2010).
} 


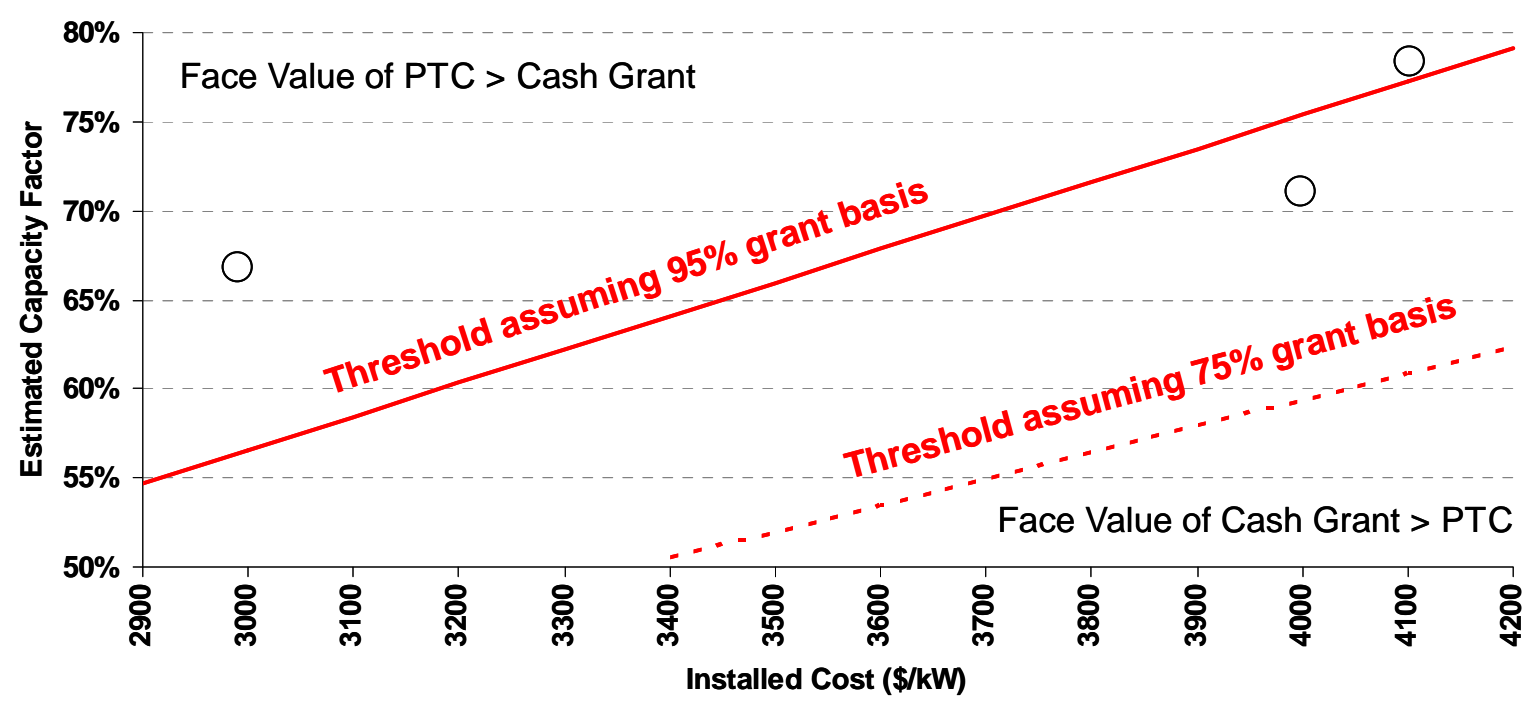

Figure 3. Relative Face Value of PTC versus Cash Grant for Geothermal Electric

As shown in Figure 3, when the grant basis is assumed to equal $75 \%$ of total installed cost, three of the four projects are found to potentially capture more face value from the PTC. When the basis increases to 95\%, one of these three projects crosses the threshold, leaving the four projects evenly split between the PTC and cash grant. Assuming a 95\% grant basis, the two projects that selected the grant even though the PTC provides greater face value forfeited about $2.0 \%$ of average installed project costs, while the two projects for which the grant provides greater face value gained roughly $8.7 \%$ of average installed project costs. Averaged across all 4 geothermal projects, the grant provided superior face value to the tune of roughly $1.8 \%$ of average installed project costs on net.

Given that none of the three owners of these four geothermal projects are likely to have sufficient U.S. tax credit appetite to make efficient use of the PTC and accelerated depreciation on their own, their unanimous selection of the grant could simply represent an attempt to bypass thirdparty tax equity investors (i.e., by self-sheltering, as discussed in Section 5.1). Alternatively, or in addition, it is possible that other factors - such as one or more of the ancillary benefits of the grant described next in Section 5.3 - outweighed face value considerations. For example, based on information presented later in Section 6.2.2, the reduction in performance risk that comes with the grant could be particularly important to some of these projects.

Together, new large wind power (85.9\%) and geothermal electric (5.9\%) projects account for nearly $92 \%$ of all grant dollars awarded as of March 1, 2010. Face value analysis is not relevant for the next-largest recipient technology - solar photovoltaic (3.7\%) - because solar already had access to the 30\% ITC (and not the PTC) prior to the passage of the Recovery Act (there is essentially no change in face value between the 30\% ITC and the cash grant). The fourth-largest recipient technology - open-loop biomass (2.8\%) - should universally favor the grant from a face-value perspective, because it is only eligible for a half PTC (i.e., \$11/MWh in 2009, rather than $\$ 21 / \mathrm{MWh}$ ), but is able to access the full 30\% cash grant. Solar thermal electric (0.5\%) falls into the same camp as solar PV: face value analysis is not relevant given that solar already had 
access to the 30\% ITC (and not PTC). In combination, these five technologies had received 99\% of all grant dollars awarded as of March 1, 2010.

\subsection{Indirect or Ancillary Value}

Although the financing advantage discussed in Section 5.1 and face value differences discussed in Section 5.2 are important considerations when evaluating the relative merits of the cash grant, ITC, or PTC for renewable power projects, they are by no means the only considerations. One must also consider the "indirect" or "ancillary" value that will flow either to or from a project, depending on which of these incentives is chosen.

Table 6. Overview of Ancillary Benefits of Choosing the Cash Grant or ITC Over the PTC

\begin{tabular}{|c|l|l|l|}
\hline $\begin{array}{c}\text { Alternative Minimum } \\
\text { Tax (AMT) }\end{array}$ & \multicolumn{1}{|c|}{ PTC } & \multicolumn{1}{|c|}{$30 \%$ ITC } & \multicolumn{1}{c|}{$30 \%$ Cash Grant } \\
for just the first 4 (of 10) years \\
$\begin{array}{c}\text { Haircut for } \\
\text { fovernment Grants }\end{array}$ & $\begin{array}{l}\text { The PTC is reduced by gov't } \\
\text { grants applied to capital costs }\end{array}$ & $\begin{array}{l}\text { The 30\% ITC/Grant is reduced only by gov't grants that } \\
\text { The AMT is taxed as income (use of grant does not matter) }\end{array}$ \\
\hline $\begin{array}{c}\text { Haircut for } \\
\text { Subsidized Financing }\end{array}$ & $\begin{array}{l}\text { The PTC is reduced by gov't- } \\
\text { subsidized low-interest loans }\end{array}$ & $\begin{array}{l}\text { The Recovery Act eliminated this haircut for the 30\% } \\
\text { ITC/grant (but not for the PTC) }\end{array}$ \\
\hline $\begin{array}{c}\text { Owner/Operator } \\
\text { Requirement }\end{array}$ & $\begin{array}{l}\text { The owner must also operate the } \\
\text { project to qualify }\end{array}$ & $\begin{array}{l}\text { No such requirement - enables leasing (and lessors } \\
\text { that elect grant can lease project to tax-exempt lessees) }\end{array}$ \\
\hline $\begin{array}{c}\text { Power Sale } \\
\text { Requirement }\end{array}$ & $\begin{array}{l}\text { Power must be sold to an } \\
\text { unrelated person to qualify }\end{array}$ & $\begin{array}{l}\text { No power sales requirement for the ITC/grant (this } \\
\text { benefits behind-the-meter projects) }\end{array}$ \\
\hline $\begin{array}{c}\text { Performance } \\
\text { Risk }\end{array}$ & $\begin{array}{l}\text { Underperformance reduces both } \\
\text { cash revenue and PTCs }\end{array}$ & $\begin{array}{l}\text { Underperformance only reduces cash revenue (does } \\
\text { not impact the 30\% ITC/grant) }\end{array}$ \\
\hline $\begin{array}{c}\text { Passive Credit/Loss } \\
\text { Limitations }\end{array}$ & $\begin{array}{l}\text { Individuals who are passive investors can only apply } \\
\text { the PTC and ITC (and losses) against passive income }\end{array}$ & $\begin{array}{l}\text { 30\% cash grant not subject to } \\
\text { passive credit limitations }\end{array}$ \\
\hline $\begin{array}{c}\text { Preference for Cash } \\
\text { Ease of Use }\end{array}$ & $\begin{array}{l}\text { In order to use, must have either sufficient income tax } \\
\text { liability or the ability to attract third-party tax equity }\end{array}$ & $\begin{array}{l}\text { Cash is highly fungible and very } \\
\text { easy to use }\end{array}$ \\
\hline
\end{tabular}

Table 6, adapted from Bolinger (2010), lists eight such ancillary benefits of a wind power project choosing the cash grant and/or ITC over the PTC. Although Bolinger (2010) discusses these ancillary benefits within the context of "community wind" projects, ${ }^{33}$ which make up a small subset of the overall wind power market, many of them are also applicable to the larger commercial wind power projects that make up the bulk of all wind power installations in the U.S., as well as to other PTC-eligible renewable power projects. Briefly, these ancillary benefits are as follows:

- The cash grant and ITC offer full relief from the alternative minimum tax (AMT), while the PTC is exempt from the AMT for just its first four years.

- The value of the PTC is reduced when a project receives certain other government grants or subsidized energy financing; these restrictions are reduced or eliminated for recipients of the cash grant or ITC.

\footnotetext{
${ }^{33}$ Loosely defined, “community wind" projects are utility-scale wind projects that feature a significantly greater share of local ownership than is common. For a variety of reasons discussed in Bolinger (2010), community wind power projects have historically had more difficulty than other utility-scale wind power projects in making efficient use of the PTC and accelerated tax depreciation. As such, community wind projects potentially stand to gain more than other projects from the Section 1603 grant.
} 
- Projects financed with leasing arrangements are not eligible for the PTC, but are eligible for the cash grant or ITC. Moreover, taxable lessors that elect the grant are able to lease projects to tax-exempt lessees (this practice is not allowed under the ITC).

- Most otherwise-eligible projects that do not sell power (e.g., projects that are interconnected on the customer, rather than utility, side of the meter) cannot use the PTC, but can use the cash grant or ITC.

- Performance risk is not as much of a risk for the cash grant or ITC as it is for the PTC.

- The PTC and ITC are subject to passive credit limitations that can restrict the types of investors in a project. The cash grant is not subject to these limitations.

- Cash is more-fungible than tax credits, which makes it more valuable - particularly when investors' appetite for tax credits subsides during turbulent economic times.

Using a pro-forma cash flow model, Bolinger (2010) finds that the value provided by just a subset of these ancillary benefits can, in aggregate, exceed the relative face value of choosing the cash grant over the PTC. ${ }^{34}$ In other words, although some of these ancillary benefits of the Treasury cash grant program are sometimes overlooked, they can provide significant value to a renewable power project, and therefore may have helped spur more renewable project installations in 2009 than would have otherwise occurred.

\footnotetext{
${ }^{34}$ Specifically, Bolinger (2010) quantified relief from the alternative minimum tax, PTC “haircuts,” the PTC's power sale requirement, and passive credit limitations. The other ancillary benefits listed in Table 6 - the ability to use lease financing, less performance risk, and a preference for cash - are also potentially important (and perhaps even more important than those items analyzed by Bolinger), but more difficult to quantify.
} 


\section{Potential Concerns with the Section 1603 Grant Program}

The Section 1603 program was created and implemented with great speed, and a number of potential concerns have subsequently been expressed about its design and implementation. These include free-ridership (and its cost), the fact that the grant rewards investment rather than performance (which could potentially lead to "gold-plating" and/or poor performance), and the location of job support (i.e., foreign versus domestic). These concerns are addressed below.

\subsection{Cost of Free-Ridership}

Section 3 estimated that of the 6,200 MW of 2009 wind power capacity that had elected the grant as of March 1, 2010, roughly 3,766 MW, or 61\%, was likely not strictly dependent on the grant, and likely would have been deployed under the PTC if the grant did not exist. Although this represents a high proportion of 'free-ridership' in 2009, the numbers are more encouraging on a quarterly basis: estimated free ridership dropped from 100\% in the first and second quarters of 2009 to 44\% in the third quarter and 32\% in the fourth quarter. This improvement reflects the passage of time, as the grant program moved beyond the legacy projects that it inherited by virtue of allowing retroactive eligibility. By the end of the year, more than 2,000 MW of wind power capacity had been built that may be directly attributable to the Section 1603 grant program.

Additionally, although free-ridership among large wind power projects was relatively high in 2009, the economic cost of this free-ridership to the U.S. Government was likely modest, in large part because wind power projects were merely choosing between the grant and other available federal incentives (i.e., the PTC or ITC). Free-ridership is considerably less costly in this situation than if the choice were instead between the grant and no other incentive at all. Moreover, for solar projects, the choice was merely whether to receive the $30 \%$ incentive in the form of an investment tax credit or a cash grant - the difference in face value between these two options is minimal, suggesting no economic impact associated with any free-ridership that may have occurred (though, as explained in Section 5.3, the cash grant does convey some additional ancillary benefits).

One can get a very general sense for the potential magnitude of the cost of free-ridership to the U.S. Government by looking back at Section 5.2, which analyzed the face value of the grant relative to the PTC. Using a 10\% nominal discount rate, that section found the grant's face value advantage over the PTC to be about $2 \%$ of installed project costs on average among all large wind and geothermal power projects that had received grants as of March 1, 2010. Because any economic advantage provided to a developer by the government can also be thought of as a cost to the government, $2 \%$ of installed project costs might also, at first blush, be considered a rough estimate of the cost of free-ridership.

The true cost of free-ridership may be less than this $2 \%$ of installed cost estimate, however, because (A) not all projects are free riders, and (B) one might argue for the use of a lower (than $10 \%$ nominal) discount rate when assessing social costs, which would serve to reduce the cost of free-ridership by increasing the cost of the PTC (relative to the grant) on a present value basis. On the other hand, the $2 \%$ of installed cost estimate does not include other potential costs to the 
U.S. Government, such as from the financing advantage provided by the grant as described in Section 5.1, from the "indirect" or "ancillary" benefits of the grant program described in Section 5.3, or from any incremental administrative costs involved with the program. As such, additional data and analysis would be needed to offer a more-comprehensive assessment of the true cost of free-ridership under the Section 1603 program. This initial estimate, however, suggests that any such cost is likely to be relatively modest.

\subsection{Grants Reward Investment Rather Than Performance}

From a policy perspective, one positive feature of the PTC is that it rewards efficient project performance, rather than investment. A better-performing project will earn more PTCs than will a poorly performing project, and those PTCs will make up a greater share of overall revenue to a low-cost project than they will to a high-cost project. In this way, the PTC encourages developers to minimize installed project costs and maximize project performance - a goal that is firmly aligned with the desired social outcome.

The cash grant and ITC, on the other hand, reward investment rather than performance. With the Federal government effectively paying 30 cents of each incremental eligible dollar spent on a project, ${ }^{35}$ there is arguably less incentive to minimize installed project costs under the grant than there is under the PTC. And with the amount of the grant not dependent on how well the project performs (as long as it meets some basic threshold considerations, such as remaining operational), there may arguably be somewhat less incentive to maximize performance under the grant (or ITC) than there is under the PTC.

Though it is true that the grant does not directly encourage lower costs and better performance, it is important to keep in mind that other market forces do support these two attributes. A project that costs less and produces more can either (A) undercut market prices while still providing an adequate return to investors, or (B) simply match market prices while providing a superior return to investors. In other words, because the grant is only one of several revenue sources required to make a project economical, its failure to encourage cost reductions and performance improvements need not lead to either widespread cost-padding (often referred to as "goldplating”) or to inferior project performance. Profit motives will still provide a strong incentive for low-cost, high-performing projects because a significant portion of revenue is earned through volumetric electricity (and renewable energy certificate) sales. Moreover, presumably few developers would willingly spend an additional dollar unnecessarily, just to get back 30 cents.

It is also important to recognize not only the technical due diligence performed by analysts for the U.S. Treasury as part of the application review process for Section 1603 grants, but also the independent third-party due diligence that most applicants have already been subjected to before they even apply for grants. These technical reviews, along with the mature nature of most of the technologies supported by the Section 1603 grant program, should help to safeguard against pervasive gold-plating and performance problems.

\footnotetext{
35 The actual percentage is higher than $30 \%$ if one also considers the benefits of depreciation deductions.
} 
Though these considerations alone suggest that any concerns that might exist about potential gold-plating or lack of performance incentives are likely misplaced, an additional assessment of both issues largely confirms this intuition.

\subsubsection{Potential Gold-Plating}

As described in Section 4, the total installed cost of each of the 40 wind power projects that had been awarded grants as of March 1, 2010 can be estimated by dividing the size of the grant by $30 \%$ to arrive at the "grant basis," and then dividing that basis by $95 \%$ (reflecting an assumption that the grant basis will, on average, be roughly 95\% of total installed project costs). This approach yields a capacity-weighted average installed cost of $\$ 2,006 / \mathrm{kW}$ for the $3,892 \mathrm{MW}$ of 2009 wind power capacity that had been awarded grants as of March 1, 2010.

This $\$ 2,006 / \mathrm{kW}$ cost estimate compares favorably with earlier expectations for installed wind power project costs in 2009. For example, based on sampling in late 2008 and early 2009, Wiser and Bolinger (2009) report that the estimated capacity-weighted average installed cost of more than 3,600 MW of U.S. wind power capacity expected to be built in 2009 was $\$ 2,120 / \mathrm{kW}$ (expressed in 2008, rather than 2009, dollars - the 2009 dollar value would be $\$ 2,145 / \mathrm{kW}$ ).

The $\$ 2,006 / \mathrm{kW}$ cost estimate for the 40 large wind power projects that had been awarded grants as of March 1, 2010 also compares favorably to the estimated cost of other wind power projects built in 2009 that did not elect the grant. Specifically, based on sampling conducted by Wiser and Bolinger (2010), the capacity-weighted average installed cost of 24 wind power projects, totaling 1,127 MW, that were built in 2009 but did not elect the grant (or at least had not as of March 1, 2010) is estimated to be $\$ 2,319 / \mathrm{kW}$.

In summary, there is no evidence to date that the investment-based nature of the Section 1603 cash grant is leading to widespread gold-plating among large wind power projects, which had received 86\% of all Section 1603 grant dollars awarded as of March 1, 2010. At this time, Berkeley Lab does not have sufficient information to conduct a similar analysis for other technologies that have received grants.

\subsubsection{Potential Performance Issues}

Assessing potential performance issues is more difficult than evaluating project costs because the projects of interest were built in 2009 and in many cases have only been operating for a few months. Nevertheless, early performance problems have, in fact, been experienced by at least three of the five eligible geothermal projects built in 2009 that have elected (or will elect) the grant. ${ }^{36}$ All three projects are working to resolve (or in some cases have already resolved) these issues, which may simply represent typical teething problems, rather than being indicative of a

\footnotetext{
${ }^{36}$ Nevada Geothermal Power's Blue Mountain project suffered a one-month outage related to electrical problems in early 2010, and has otherwise been operating below its rated capacity of 49.5 MW (Nevada Geothermal Power, 2010). Raser's Thermo 1 project has been operating at less than half its rated capacity due to lower-than-expected water temperatures (Oberbeck, 2009). Ormat's 50 MW North Brawley project (which intends to apply for the grant) has not yet been able to operate at a steady state above $17 \mathrm{MW}$ due to a problem surrounding un-dissolved solids in the geothermal fluid (Ormat Technologies, 2010).
} 
fundamental problem with the grant program itself. (That said, these early set-backs do make it easier to understand, from a performance-risk perspective, the apparent widespread appeal of the cash grant to geothermal projects). There appear to be fewer (or at least fewer publicized) performance issues with wind power projects built in $2009 .{ }^{37}$ Nonetheless, it would be logical to think that the Section 1603 grant program may (understandably) be influencing wind power project developers to build the lower capacity factor projects in their portfolio, but it is too early to tell with any degree of confidence whether this is, in fact, the case. Even if it were the case, there is no reason to believe that such behavior would lead to poor project performance per se.

While actual performance data will not be available for some time, and a full analysis of potential performance concerns associated with the grant program is therefore not yet possible, the qualitative considerations discussed earlier (namely that over $50 \%$ of aggregate project revenue is typically delivered though performance-based electricity sales) suggest at this time that the grant program is unlikely to result in any significant degradation of project-level performance relative to the PTC.

\subsection{Location of Job Support}

The Section 1603 program has been criticized by some for potentially supporting more overseas than domestic jobs. This criticism was first prompted by news of a large wind power project under development in Texas that plans to use Chinese-made turbines (the first sizable project in the U.S. to do so) and that also plans to apply for the grant (Cielo Wind Power, 2009). It has been further fueled by several stories aired by the Investigative Reporting Workshop of the American University School of Communication that note (among other things) that most grant dollars have gone to wind power developers that are headquartered outside of the U.S., and/or to projects using wind turbines manufactured by companies that are headquartered outside of the U.S. (Choma 2010a, 2010b). These concerns have led to calls to subject the Section 1603 program to "Buy American” provisions (Schumer 2009, Schumer et al. 2010), which would require that grants only be awarded to projects using turbines made in the U.S.

The U.S. wind power industry, meanwhile, has responded to this criticism (AWEA 2010a, 2010b) by noting that grant money goes directly to wind power projects located in the U.S. (i.e., not to wind turbine manufacturers), that the "domestic content" of an average wind power project is in excess of 50\% (even if the turbine manufacturer is headquartered overseas), and that this domestic proportion has been increasing in recent years as a result of favorable policies such as the Section 1603 grant program.

No amount of analysis can identify the “correct” policy response to such concerns. NREL's JEDI model can, however, be used to potentially inform the debate. Although the model cannot estimate the number of foreign jobs supported by the Section 1603 grant program (because the IMPLAN multipliers used in the model are specific to the U.S.), it can be used to estimate how

\footnotetext{
${ }^{37}$ Wind power projects have the advantage of being made up of many individual turbines, any one of which could fail without substantially degrading overall project performance. That said, one incident of note involves a March 2009 turbine collapse at the 97.5 MW Noble Altona project in New York (this project has elected the cash grant). A second turbine was also damaged at the time but did not collapse, and the rest of the project was temporarily shut down. Noble plans to replace the damaged turbines.
} 
many more U.S. jobs might have been supported if $100 \%$ of the 2009 wind power capacity that elected the grant could have been sourced entirely domestically. ${ }^{38}$

Table 7 presents results from re-running the JEDI model under all of the same assumptions discussed earlier in Section 4, but this time assuming a 100\% local share for all cost items. As expected, the results do not differ much from those presented earlier in Table 5 for either operational jobs or onsite construction jobs, since those jobs are largely assumed to be located domestically regardless of the origin of the materials used. The number of supply chain and induced jobs supported during the construction phase, however, increases significantly - by more than 82,000 or by roughly $65 \%$ (compared to Table 5), split more or less evenly between supply chain and induced impacts.

Table 7. Gross Job Estimates from the JEDI Model (assuming $100 \%$ overall domestic content)

\begin{tabular}{|c|r|r|r|r|}
\hline & & $\begin{array}{c}\text { Awarded } \\
\text { Projects }\end{array}$ & $\begin{array}{c}\text { Pending } \\
\text { Projects }\end{array}$ & $\begin{array}{c}\text { Total } \\
\end{array}$ \\
\hline & Number of Projects & 40 & 31 & 71 \\
& Aggregate Capacity (MW) & $3,892 \mathrm{MW}$ & $2,311 \mathrm{MW}$ & $6,202 \mathrm{MW}$ \\
\hline Construction Phase & Project development and onsite labor impacts & 4,218 & 2,462 & 6,680 \\
(Gross short-term jobs: & Turbine and supply chain impacts & 68,655 & 40,636 & 109,291 \\
FTE for 1 year) & $\underline{\text { Induced impacts }}$ & $\underline{62,385}$ & $\underline{36,912}$ & $\underline{99,297}$ \\
\hline $\begin{array}{c}\text { Operational Phase } \\
\text { (Gross long-term jobs: }\end{array}$ & Total Construction Phase: & $\mathbf{1 3 5 , 2 5 8}$ & $\mathbf{8 0 , 0 1 0}$ & $\mathbf{2 1 5 , 2 6 8}$ \\
FTE for 20-30 years) & Onsite labor impacts & 227 & 130 & 357 \\
\hline
\end{tabular}

As with Table 5 earlier, the results presented in Table 7 pertain to all large 2009 wind power projects that have elected the Section 1603 cash grant in lieu of the ITC or PTC, and must be multiplied by 39\% (i.e., 2,400 MW / 6,200 MW) to remove the impact of free-ridership. Doing so yields roughly 83,300 gross short-term job-years during the construction phase, and roughly 3,940 gross long-term jobs during the operational phase. In other words, if domestic manufacturing and labor could have supplied 100\% of the 2,400 MW of 2009 wind power capacity potentially enabled by the Section 1603 grant program, then roughly 31,700 additional gross job-years (83,300 vs. the 51,600 reported in Section 4) would have been supported during the construction phase, while only about 80 additional gross long-term jobs (3,940 vs. the 3,860 reported in Section 4) would be supported during the operational phase.

In conclusion, given the current reality of wind turbine manufacturing in the U.S. (i.e., 60\% domestic content rather than 100\%), the JEDI model estimates that the Section 1603 grant program has supported about $62 \%$ of the maximum number of (short-term) job-years that it could have possibly hoped to support (if domestic content were, in fact, 100\%) during the

\footnotetext{
${ }^{38}$ It should be noted that this is merely a hypothetical exercise. Even if a few wind turbine manufacturers do currently have a sufficient U.S. manufacturing presence to supply fully-domestic wind turbines, the amount of installed wind capacity that is relevant to this discussion - 6,200 MW - is likely to be well beyond their present means.
} 
construction phase of wind power projects built in 2009, and about $98 \%$ of the maximum number of long-term jobs that it could possibly support during the operational phase of those projects.

Although this analysis suggests that there is room for improvement in terms of shifting foreign wind turbine manufacturing jobs to the U.S., it is also important to emphasize that this analysis is, at least in the near term, merely a hypothetical exercise - i.e., U.S. wind turbine manufacturing is not currently capable of supplying $100 \%$ of the wind power capacity seeking Section 1603 grants. As such, subjecting the Section 1603 grant program to "Buy American" provisions would not be expected to fully bridge the domestic "jobs gap" in the near term. In fact, absent the ability to currently source $100 \%$ domestic content, any requirement to do so would, in the near term, necessarily reduce wind power installations relative to what they might otherwise be under the current program design. Depending on the magnitude and duration of this slowdown in project installations, a $100 \%$ domestic content requirement could yield nearterm domestic job losses relative to the current program design. 


\section{Conclusions}

This section summarizes key findings from this initial attempt at a selective evaluation of the first year of the Section 1603 program.

The Section 1603 cash grant program has been heavily subscribed by renewable project developers. As of March 1, 2010, 64\% of the eligible wind power capacity and $100 \%$ of the eligible geothermal capacity built in 2009 had either elected, or planned to elect, the cash grant rather than the PTC or ITC. These two technologies had been awarded 92\% of the nearly \$2.6 billion in Section 1603 grant dollars distributed through March 1. Based on less-complete information, it appears as if most or all open-loop biomass and solar thermal electric capacity built in 2009 also elected the grant, while a lower proportion of solar photovoltaic and landfill gas capacity chose the grant. Although large wind power projects have dominated the program to date, a wide array of technologies have applied for and received Section 1603 grants.

The grant program may have helped directly motivate as much as 2,400 MW of wind power capacity to be built that would not otherwise have come online in 2009. Comparing actual 2009 wind power capacity additions to what had been expected in late 2008 and early 2009, and then bluntly attributing 50\% of the outperformance to the Section 1603 grant program, yields a rough estimate of about 2,000 MW that may have been enabled by the grant. A more-refined approach to identifying free-riders (i.e., those projects that would likely have come on-line in 2009 even without the Section 1603 program), which examines each individual 2009 wind power project that has elected the grant, yields a slightly higher estimate of roughly 2,400 MW that may have been directly enabled by the grant program.

The 2,400 MW of wind power capacity that may have been enabled by the grant are estimated to have supported approximately 51,600 short-term full-time-equivalent (FTE) gross job-years during the construction phase, and 3,860 gross long-term FTE jobs during the operational phase. These estimates are derived from NREL's JEDI model; are inherently uncertain; include onsite labor, supply chain impacts, and induced jobs; are based on an estimate of roughly $60 \%$ domestic content in average U.S. wind power projects; and represent jobs based in the U.S. Most construction-phase jobs are considered to be short-term in nature (and are therefore expressed as job-years), while operational-phase jobs are assumed to last for the duration of the project (e.g., 20-30 years). It is important to reiterate that these estimates are of gross jobs - e.g., the JEDI model does not account for potential job losses at non-wind power plants as wind power displaces non-wind generation - and that a full employment analysis would need to consider macroeconomic influences and net jobs.

The Section 1603 cash grant program provides significant economic value to many renewable power projects. The grant's economic value to renewable energy projects, relative to the PTC or even the 30\% ITC, can be broken down into three non-overlapping components: the financing advantage that it provides when tax equity is scarce and/or expensive, its "direct" or "face" value, and its "indirect" or "ancillary" benefits.

- The grant program reduces the market's dependence on scarce and/or costly third-party tax equity. With the cash grant in hand, "self-sheltering" a project's remaining federal tax benefits (i.e., carrying forward any unused depreciation deductions) rather than "paying” a 
third-party tax equity investor to monetize them is a significantly more-viable proposition than trying to self-shelter both depreciation and the PTC (or ITC). As a result, many 2009 wind power projects that selected the grant have reportedly taken this approach - i.e., borrowing project-level term debt (rather than seeking tax equity) and carrying depreciation deductions forward in time until they can be absorbed by the project itself. Rough analysis suggests that, for an average wind power project, the value of self-sheltering the grant rather than the PTC comes to around 8\% of installed project costs (or 100 basis points of return). This financing advantage may also be particularly relevant to smaller projects that are not large enough to attract third-party tax equity.

- The grant program also provides significant "direct" or "face" value to many renewable power projects. Analysis of the face value of the grant relative to the PTC (i.e., the relative "as-stated" after-tax economic value of these two incentives) reveals that 30 of the 40 wind power projects that had been awarded grants as of March 1, 2010 likely receive more face value - to the tune of about $4.2 \%$ of installed project costs on average - from the grant than they would have from the PTC. The remaining 10 wind power projects forfeit, on average, face value on the order of $2.5 \%$ of installed project costs. On net across all 40 wind power projects, the face value advantage of the grant comes to about $2.2 \%$ of installed project costs on average. Similar analysis of four geothermal projects yields more-mixed results: two projects receive more face value from the PTC while the other two favor the grant, with the balance across all four projects favoring the grant by about $1.8 \%$ of installed project costs on average. Because the grant is received in the project's first year while the PTC is earned over a 10-year period, choice of discount rate impacts face value calculations: a higher discount rate reduces the present value (or cost) of the PTC relative to the grant, while a lower discount rate has the opposite effect.

- The grant also conveys a number of "indirect" or "ancillary" benefits that, although often overlooked, can provide significant economic value to projects. These include full relief from the alternative minimum tax, elimination of "PTC haircuts" caused by the use of other government grants or subsidized energy financing, the ability to pursue leasing (even to taxexempt lessees) as a viable financing option, compatibility with behind-the-meter projects, relief from passive credit limitations, a reduction in performance risk, and a general preference for cash (particularly during turbulent times).

Concerns with the design or implementation of the program have, in some cases, received considerable attention, and include the cost of free-ridership, the fact that grants reward investment rather than performance, and the location of job support.

- As the grant program works through the backlog of legacy projects that it inherited as a result of retroactive eligibility back to the start of 2009, a growing number of wind power projects appear to have been directly motivated by the grant. Furthermore, the cost of free-ridership to the U.S. Government during 2009 was likely modest, since projects were choosing between the grant and other similar federal incentives (i.e., the PTC and ITC), as opposed to choosing between the grant and no other incentive.

- The fact that grants reward investment rather than performance raises the specter of potential "gold-plating” and/or performance problems among grant recipients. Analysis of these issues is complicated by the fact that all of the projects in question are still quite new. 
Nevertheless, the analysis presented in this paper finds no compelling and widespread evidence to date of gold-plating among large wind power projects, and little (if any) evidence of performance issues beyond what might be expected as part of the normal "teething process” as projects ramp up to full production.

- Though not capable of estimating foreign job support, NREL's JEDI model was used to estimate how many more U.S. jobs would have been supported if $100 \%$ of the roughly 2,400 MW of 2009 wind power capacity that may have been driven by the Section 1603 grant program could have been sourced domestically. Given the current reality of wind turbine manufacturing in the U.S. (i.e., $60 \%$ domestic content rather than $100 \%$ ), the JEDI model estimates that the Section 1603 grant program has supported about 62\% of the maximum number of job-years that it could possibly have supported (if domestic content were, in fact, $100 \%$ ) during the construction phase, and about $98 \%$ of the maximum number of long-term jobs that it could possibly support during the operational phase. Although this analysis suggests that there is room for improvement in terms of shifting foreign wind turbine manufacturing jobs to the U.S., it is also important to emphasize that this analysis is, at least in the near term, merely a hypothetical exercise - i.e., U.S. wind turbine manufacturing is not currently capable of supplying 100\% of the wind power capacity seeking Section 1603 grants. As such, subjecting the Section 1603 grant program to "Buy American” provisions would not be expected to fully bridge the domestic "jobs gap" in the near term. In fact, absent the ability to currently source $100 \%$ domestic content, any requirement to do so would necessarily reduce wind power installations in the near term relative to what they might otherwise be under the current program design. Depending on the magnitude and duration of this slowdown in project installations, a 100\% domestic content requirement could yield near-term domestic job losses relative to the current program design. 


\section{ACKNOWLEDGMENTS}

The work described in this report was funded by the U.S. Department of Energy's Office of Electricity Delivery and Energy Reliability (Permitting, Siting, and Analysis Division) and Office of Energy Efficiency and Renewable Energy (Wind \& Hydropower Technologies Program) under Contract No. DE-AC02-05CH11231.

\section{DISCLAIMER}

This document was prepared as an account of work sponsored by the United States Government. While this document is believed to contain correct information, neither the United States Government nor any agency thereof, nor the Regents of the University of California, nor any of their employees, makes any warranty, express or implied, or assumes any legal responsibility for the accuracy, completeness, or usefulness of any information, apparatus, product, or process disclosed, or represents that its use would not infringe privately owned rights. Reference herein to any specific commercial product, process, or service by its trade name, trademark, manufacturer, or otherwise, does not necessarily constitute or imply its endorsement, recommendation, or favoring by the United States Government or any agency thereof, or the Regents of the University of California. The views and opinions of authors expressed herein do not necessarily state or reflect those of the United States Government or any agency thereof or the Regents of the University of California. 


\section{References}

American Wind Energy Association (AWEA). 2010a. AWEA Statement on Senators Schumer, Casey, Brown and Tester Urging Administration to Suspend Stimulus Program. March 3, 2010. http://www.awea.org/newsroom/releases/03-3-10-AWEA_Statement_on_Senators_and_Stimulus.html

2010b. American Wind Energy Association Response to American University Study/ABC World News Study. February 11, 2010. http://www.awea.org/newsroom/releases/02-11-10_RS Response to ABC.html

2010c. AWEA Year-End 2009 Market Report. January 26, 2010.

http://www.awea.org/publications/reports/4Q09.pdf

2009. Annual Wind Industry Report: Year Ending 2008. Washington, DC: American Wind Energy Association. April 13, 2009. http://www.awea.org/publications/reports/AWEA-Annual-Wind-Report2009.pdf

Bolinger, Mark. 2010. Revealing the Hidden Value that the Federal Investment Tax Credit and Treasury Cash Grant Provide to Community Wind Projects. LBNL-2909E. Berkeley, Calif.: Lawrence Berkeley National Laboratory. http://eetd.lbl.gov/EA/EMP/reports/lbnl-2909e.pdf

Bolinger, Mark, Ryan Wiser, Naïm Darghouth. 2010. Preliminary Evaluation of the Impact of the Section 1603 Treasury Grant Program on Renewable Energy Deployment in 2009. LBNL-3188E. Berkeley, Calif.: Lawrence Berkeley National Laboratory. http://eetd.lbl.gov/EA/EMP/reports/lbnl-3188e.pdf

Bolinger, Mark, Ryan Wiser, Karlynn Cory, Ted James. 2009. PTC, ITC, or Cash Grant? An Analysis of the Choice Facing Renewable Power Projects in the United States. LBNL-1642E. Berkeley, Calif.: Lawrence Berkeley National Laboratory. http://eetd.lbl.gov/EA/EMP/reports/lbnl-1642e.pdf

Broehl, Jesse. 2010. "United States: Leading market grows in the gloom.” Windpower Monthly. Volume 26, Number 3, March 2010, pp. 40-42.

BTM Consult. 2009. International Wind Energy Development: World Market Update 2008. Ringkobing, Denmark: BTM Consult ApS.

Chadbourne \& Parke. 2010a. “Update: Tax Equity Market.” Project Finance Newswire. April 2010. pp. 8-20. . 2010b. “Update: Tax Equity and Debt Markets.” Project Finance Newswire. February 2010. pp. 28-35. 34. . 2009. “Trends in Tax Equity for Renewable Energy.” Project Finance Newswire. January 2009, pp. 27. 2008. “State of the Tax Equity Market.” Project Finance Newswire. November 2008. pp. 22-36.

Choma, Russ. 2010a. "Most Wind Grants Go To Overseas Firms.” Investigative Reporting Workshop of the American University School of Communication, February 8, 2010. http://investigativereportingworkshop.org/investigations/wind-energy-funds-going-overseas/story/most-windgrants-go-overseas-firms/

. 2010b. "Renewable Energy Money Still Going Abroad, Despite Criticism from Congress.” Investigative Reporting Workshop of the American University School of Communication, February 8, 2010. http://investigativereportingworkshop.org/investigations/wind-energy-funds-going-overseas/story/renewableenergy-money-still-going-abroad/ 
Cielo Wind Power. 2009. “U.S. Renewable Energy Group, China’s Shenyang Power Group, and Cielo Wind Power to Develop a 600 MW Wind Farm in Texas.” October 29, 2009. http://www.cielowind.com/news/pressreleases/us-renewable-energy-group-china\%E2\%80\%99s-shenyang-power-group-and-cielo-wind-power-todevelop-a-600-mw-wind-farm-in-texas

Council of Economic Advisers. 2010. "The Economic Impact of the American Recovery and Reinvestment Act of 2009: Second Quarterly Report.” January 13, 2010. http://www.recovery.gov/About/Documents/100113economic-impact-arra-second-quarterly-report.pdf

David, Andrew S. 2009. Wind Turbines: Industry \& Trade Summary. United States International Trade Commission, Office of Industries, Publication ITS-02, June 2009. http://www.usitc.gov/publications/332/ITS2.pdf

Eber, John. 2009. Presentation at WINDPOWER 2009, Chicago, Illinois, May 6, 2009.

Edison International. 2010. Transcript of Edison International's Q4 2009 Earnings Call. Accessed at http://seekingalpha.com/article/191324-edison-international-q4-2009-earnings-call-transcript?page=-1

Energy Information Administration (EIA). 2009a. Annual Energy Outlook 2009 (Updated Reference Case Service Report, April 2009). DOE/EIA-0383(2009). Washington D.C.: Energy Information Administration.

. 2009b. Annual Energy Outlook 2009 (Originally Published Reference Case, March 2009). DOE/EIA0383(2009). Washington D.C.: Energy Information Administration.

Feo, Ed. 2010. “Smoother Sailing For Project Finance Predicted This Year.” North American Windpower, Volume 7, Number 2, March 2010. pp. 1, 19-20, 22.

Gawell, Karl and Leslie Blodgett. 2009. “Geothermal Energy on Launch Trajectory in 2009.” Geothermal Energy Association. December 14, 2009.http://www.geoenergy.org/pressReleases/Geothermal_Energy_On_Launch_Trajectory_in_2009_-_December_14_2009.pdf

GlobalData. 2009. The US Wind Energy Market Analysis and Forecasts to 2013. February 2009.

Hays, K. 2009. "Wind in the Mix: Staying Competitive in the Downturn." WINDPOWER 2009, Chicago, Illinois, May 5, 2009.

Hudson Clean Energy Partners. 2009. "The Impact of Stimulus Bill Policy Choices on the Renewable Energy Industry.” Capitol Hill briefing, January 15, 2009.

Kirkegaard, Jacob Funk, Thilo Hanemann, and Lutz Weischer. 2009. It Should Be A Breeze: Harnessing the Potential of Open Trade and Investment Flows in the Wind Energy Industry. WP 09-14 of the Working Paper Series, World Resources Institute and the Peterson Institute for International Economics. December 2009. http://pdf.wri.org/working_papers/it_should_be_a_breeze.pdf

Martin, Keith. 2010. “Treasury Cash Grant Update.” Project Finance Newswire. February 2010. pp. 17-22.

Nevada Geothermal Power. 2010. “Faulkner 1 Power Outage - Investigation Underway.” January 22, 2010. http://www.nevadageothermal.com/s/News.asp

New Energy Finance (NEF). 2009a. USQ4 Wind Financing Update. October 26, 2009. London, UK: New Energy Finance.

. 2009b. Q1 Wind Industry Outlook. April 3, 2009. London, UK: New Energy Finance.

Finance.

2008. US Wind Financing Flux and 2009 Market Size. October 23, 2008. London, UK: New Energy 
Oberbeck, Steven. 2009. “Utah Geothermal Plant Runs Into Cold-Water Problem.” The Salt Lake Tribune, September 18, 2009. http://www.sltrib.com/business/ci_13360860

Ormat Technologies. 2010. North Brawley Power Plant Placed in Service; Currently Generating 17 MW; Additional Operations Update. February 9, 2010. http://www.ormat.com/news.php?did=137\&aid=21bb4e6c5d3bad843c809aee81d7ef66

Schumer, Charles E. 2009. “Schumer Urges Obama Administration To Block \$450M In Stimulus Funds Sought By Wind Farm Project With Parts Built In China.” November 5, 2009 press release. http://schumer.senate.gov/new_website/record.cfm?id=319695\&

Schumer, Charles E., Robert P. Casey Jr., Sherrod Brown, Jon Tester. 2010. “Schumer, Casey, Brown \& Tester Urge Obama Administration To Suspend Stimulus Program Funneling Billions Overseas.” March 3, 2010 press release. http://schumer.senate.gov/record.cfm?id=322732\&

Solar Energy Industries Association (SEIA). 2010. “US Solar Industry: Year in Review 2009.” April 15, 2010. http://seia.org/galleries/default-file/2009\%20Solar\%20Industry\%20Year\%20in\%20Review.pdf

U.S. Department of the Treasury. 2009. "Payments for Specified Energy Property in Lieu of Tax Credits under the American Recovery and Reinvestment Act of 2009: Program Guidance.” http://www.treasury.gov/recovery/docs/guidance.pdf

Wei, Max, Shana Patadia, Daniel M. Kammen. 2010. "Putting renewables and energy efficiency to work: How many jobs can the clean energy industry generate in the US?” Energy Policy. Vol 38, Issue 2, February 2010, pp. 919-931.

Wiser, Ryan and Mark Bolinger. 2010 (forthcoming). 2009 Wind Technologies Market Report. Berkeley, Calif.: Lawrence Berkeley National Laboratory. . 2009. 2008 Wind Technologies Market Report. LBNL-2261E. Berkeley, Calif.: Lawrence Berkeley National Laboratory. http://eetd.lbl.gov/EA/EMP/reports/2008-wind-technologies.pdf 